\title{
Research Paper \\ Effectiveness of Mother-Child Rhythmic Movement Games Training on the Reduction of Verbal and Nonverbal Aggression in Children
}

Sepideh Nayeb Hoseinzadeh ${ }^{1}$, Ali Aghaziarati ${ }^{* 2}$, Somayyeh Hematipouya ${ }^{3}$, Kiyana Karavan Borojardi ${ }^{4}$

1. Ph.D. Student of Psychology of Exceptional Children, Science and Research Branch, Islamic Azad University, Tehran, Iran

2. Ph.D. Student of Psychology and Education of children with Special Needs, Faculty of Psychology and Educational Sciences, University of Isfahan, Iran

3. M.A. in Clinical Psychology, Faculty of Educational Sciences and Psychology, Al-Zahra University, Tehran, Iran 4. M.A. in General Psychology, West Tehran Branch, Islamic Azad University, Tehran, Iran

Citation: Nayeb Hoseinzadeh S, Aghaziarati A, Hematipouya S, Karavan Borojardi K. Effectiveness of mother-child rhythmic movement games training on the reduction of verbal and nonverbal aggression in children. Quarterly Journal of Child Mental Health. 2020 ; 7(3): $234-247$.

\section{http://dx.doi.org/10.52547/jcmh.7.3.19}

\section{A R T I C L E I N F O}

\section{Keywords:}

Rhythmic movement

games,

mother-child,

verbal and nonverbal

aggression

Received: 14 Aug 2018

Accepted: 11 Nov 2018

Available: 7 Dec 2020

\section{A B S T R A C T}

Background and Purpose: Aggression is one of the most common behavioral problems in children, which is mostly the result of troubled and unhealthy structure of the family and poor parent-child relationship. Thus, this study was done to determine the effectiveness of mother-child rhythmic movement games training on reducing verbal and nonverbal aggression in 3 to 5 year-old children.

Method: The present study was a quasi-experimental study with a control group pretest-posttest design and a two-month follow-up period. The population included 3 to 5 year-old girls and boys attending the kindergarten of Shahid Beheshti University in 2017. After screening with Aggression Scale (Vahedi et al., 2008), 18 girls and boys together with their mothers were selected by convenience sampling and then assigned to either the experimental or control group. Mothers and children of the experimental group received 10 sessions of rhythmic movement games training, while the control group received no intervention. Data were analyzed by repeated measures analysis of variance.

Results: Findings showed a significant difference between the experimental and control group in terms of general aggression $(F=6.68, P=0.02)$, verbal-invasive aggression $(F=16.59, P=0.001)$, physical-invasive aggression $(\mathrm{F}=14.16, \mathrm{P}=0.002)$ and relational aggression $(\mathrm{F}=22.36, \mathrm{P}=0.000)$ in the post-test and follow-up phases.

Conclusion: According to the results of this study, it can be said that using rhythmic movement games, children learned to deal with stimuli and extended it to their surroundings, especially in relation to peers, which reduced g verbal and non-verbal aggression in them. As a result, this method can be used as a supplementary method along with other therapies for this disorder.

\footnotetext{
* Corresponding author: Ali Aghaziarati, Ph.D. Student of Psychology and Education of children with Special Needs, Faculty of Psychology and Educational Sciences, University of Isfahan, Iran.

E-mail addresses: Ali_ziarati99@yahoo.com
} 


\section{تأثير آموزش بازىهاى حر كتى موزون مادر -كود كى بر كاهش برخاشكرى كلامى و غير كلامى كود كان

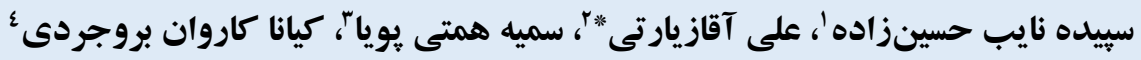

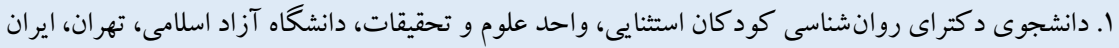

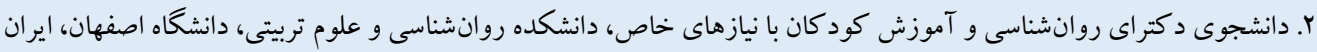

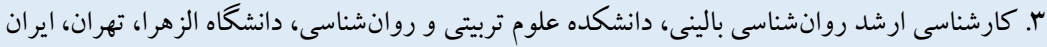

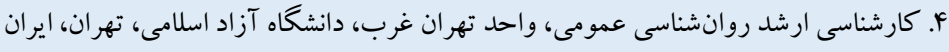

\begin{tabular}{|c|c|}
\hline جكيده & 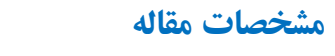 \\
\hline زمينه و هدف: يُرخاشكرى يكى از عمده ترين مشكلات رفتارى در كود كان است كه بيشتر نتيجه خانوادههاى ساز ماننايافته، ساختار ناسالم، & 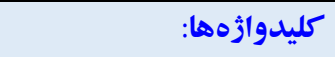 \\
\hline و نحوه ارتباط نامطلوب والدين با كودكك است؛ بدين ترتيب يُووهش حاضر با هدف تعيين ميزان اثربخشى آموزش بازىهاى حر كتى & 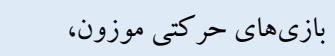 \\
\hline 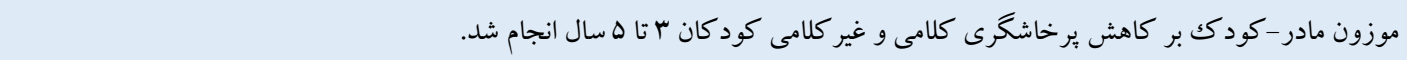 & 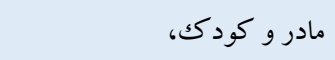 \\
\hline 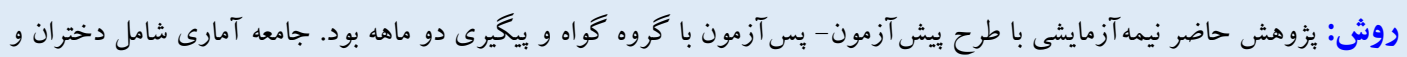 & 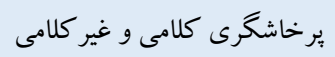 \\
\hline 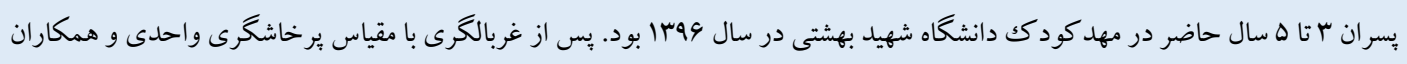 & \\
\hline 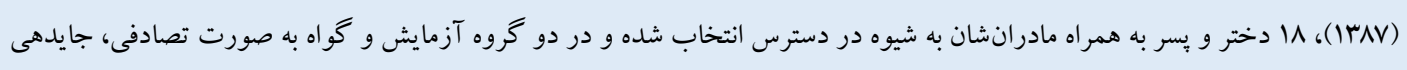 & \\
\hline شدند. كود كان و مادران گروه آزمايشى به مدت . ا جلسه تحت آموزش بازىهاى حركتى موزون مادر -كودكى قرار كرفتند، اما گروه & \\
\hline كواه هيج مداخلهاى دريافت نكرد. دادهها با استفاده از روش آمارى تحليل واريانس اندازههاى مكرر تحليل شد. & \\
\hline 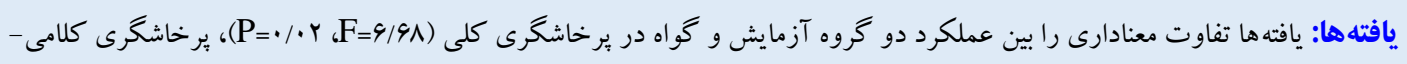 & \\
\hline 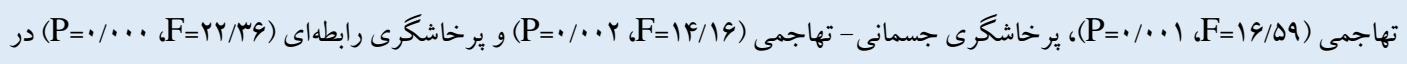 & \\
\hline مر حله بِ آزمون و بِ از دو ماه بِيكيرى نشان داد. & در افت شده: r/R/ه \\
\hline نتيجه كيرى: با توجه به نتايج بزوهش مىتوان كفت كه كود كان با استفاده از بازىهاى حر كتى موزون، نحوه رويارويى با محر كهها را & 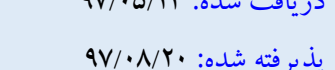 \\
\hline آموخته و آن را به محيط اطراف خود و به خصوص در ارتباط با همسالان تعميم دادند و در نتيجه يرخاشكرى كلامى و غير كلامى در آنها & $99 / .9 / 1 \mathrm{Q}: 0 \mathrm{~d}$ \\
\hline كاهش يافت؛ بنابراين اين شيوه مىتواند به عنوان يك شيوه تكميلى در كنار درمانهاى اصلى اين اختلال به كار رود. & \\
\hline
\end{tabular}

* نويسنده مسئول: على آقازيارتى، دانشجوى دكتراى روانشناسى و آموزش كود كان با نيازهاى خاص، دانشكده روانشناسى و علوم تربيتى، دانشكاه اصفهان، ايران.

Ali_ziarati99@yahoo.com راياناهـ

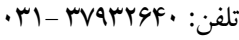


رفتارها به صــورت نظامدار در ارتباط هدفمند مادر و كودكك ســازمان

مى يابد (1) (1)

يثزوهش هايى كه درباره مشـكلات رفتارى انجام شــده اسـت، اغلب

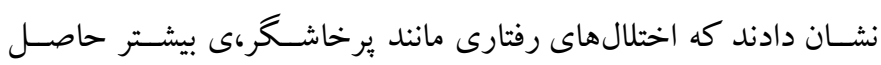

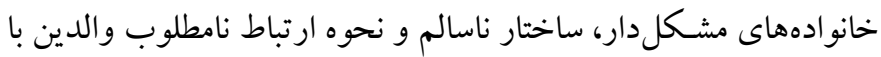

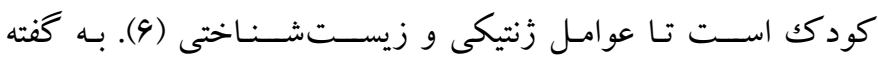
روانشـناسان اجتماعى مخربترين نيرو در روابط اجتماعى، يرخاشخرى

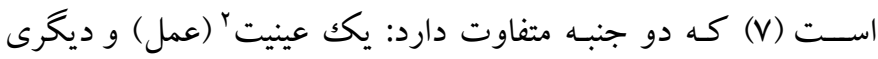

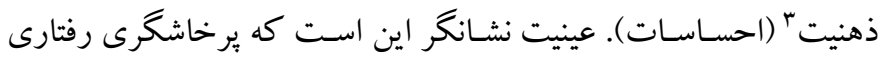

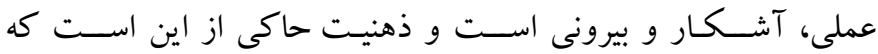
يرخاشـرى همراه با يكك احسـاس درونى است؛ اين احساس تركيبى از

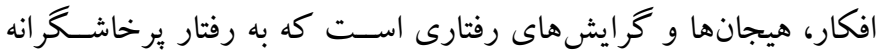

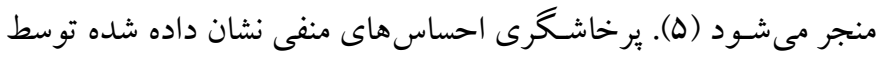

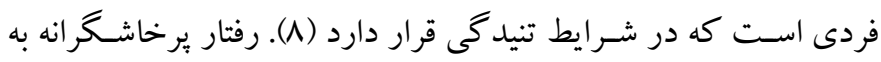
عنوان اقدامى نسـبت به فرد يا شسى خاص با هدف صـدمه يا ترسـاندن

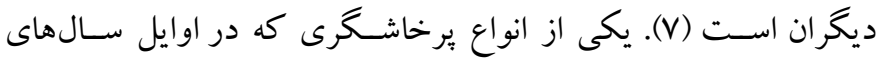

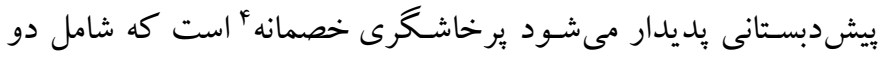

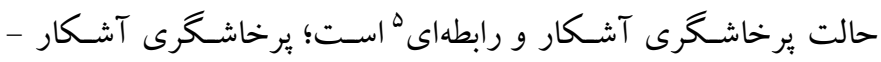
فيزيكى و نوع كلامى צكه شامل رفتارهاى خصمانه مانند زدن، هل داد دادن،

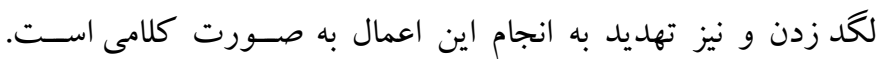

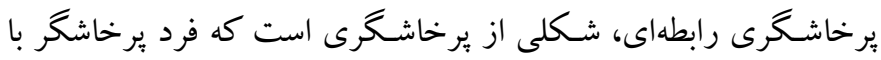

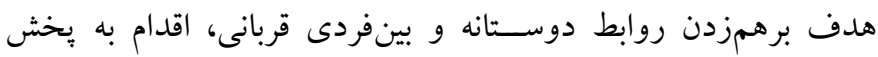

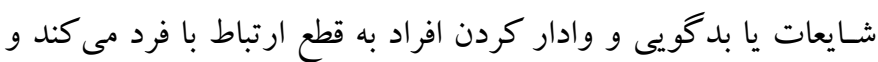

از اين طريق باعث منزوى شدن او مىشود (9).

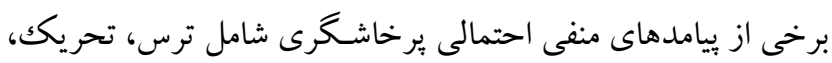

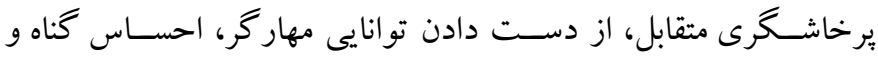

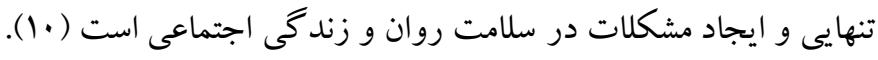

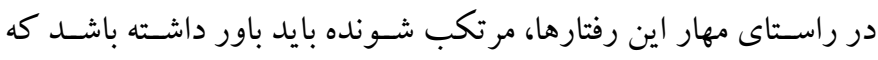
رفتارش با هدف آسـيب رسـاندن به ديخرى بوده و ييامد آن برانگيختن

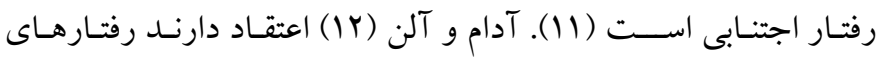

4. Hostile

5. Obvious \& relational

6. Obvious - physical \& verbal
مقام

هنگًام انديشـيدن به تغيير رفتار كود كان، مى توان در سـه كسـتره متمر كز

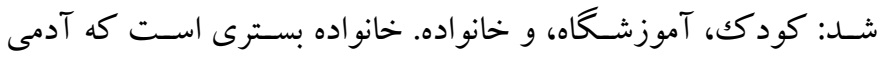

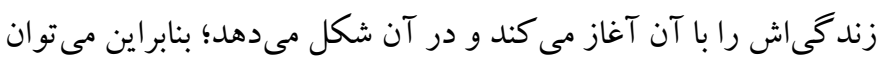

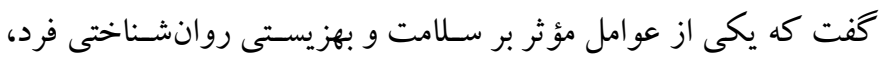
كيفيت عملكرد سـيستم خانو اده اسـت و در اين ميان روابط و تعاملات حاكم بر اعضا و زيرسيستمهاى خانو اده از اهميت خاصى برخوردار است

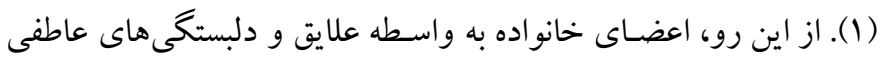

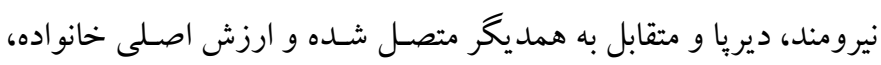
حاصل از شبكه روابطى است كه توسط اعضاى آن به وجود آمده است (Y). در دهلهاى اخير روانشـاسان بر روابط كودكك با مراقبانش تأكيد

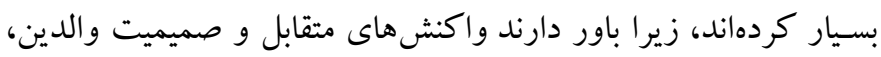
اسـاس تحول شـناختى -عاطفى كودكك را تشـكيل داده و خطر ابتلاى كودكك به اختلالهاى روانى را كاهش مىدهد (r). از اين رو، بررسى سوسى

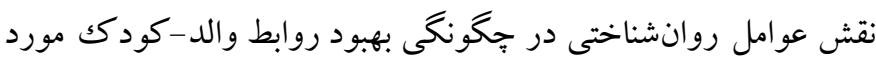
توجه روانشناسان سلامت است.

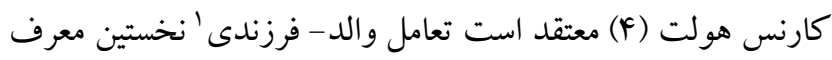

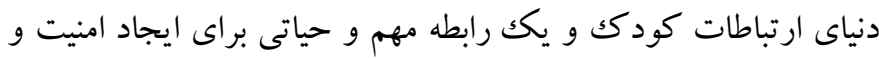

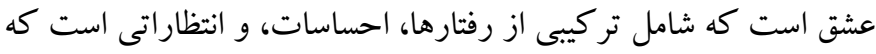
منحصـر به بدر و مادر خاص و يكك كودكك خاص مى شــود. درباره

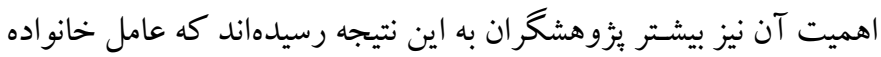

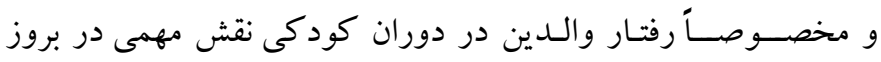

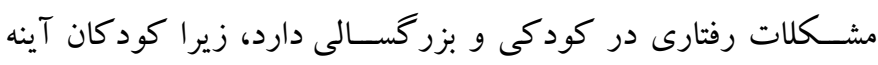

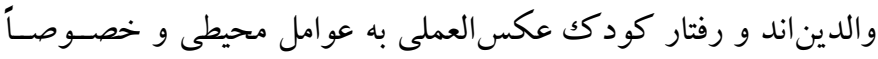

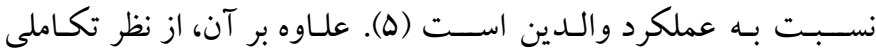

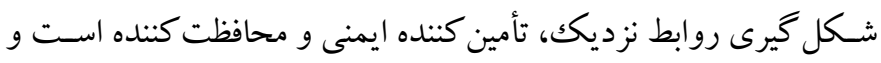
در نهايت شـانس بقاى كودكك را افزايش مى دهد. وقتى كودكك از مادر

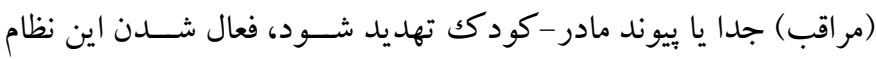

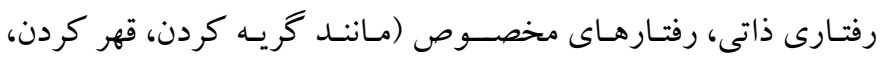

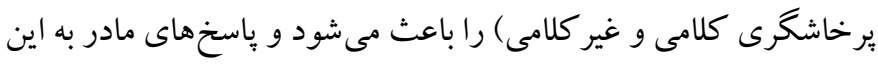

1. Parent child

2. Objectivity

3. Mentality 
بروننمود " كودكان كاهش، و توانايى يادگيرى آنها افزايش يافت. از

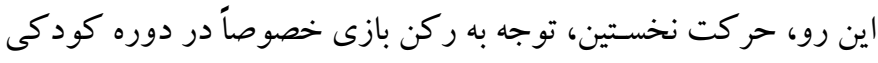

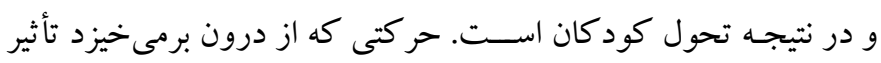

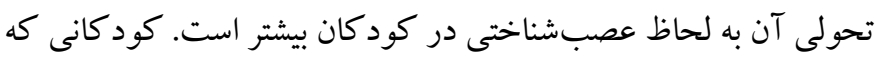

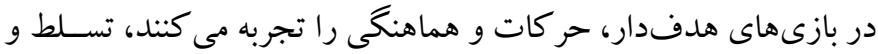

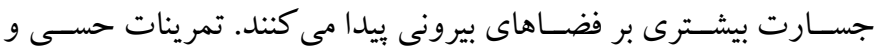

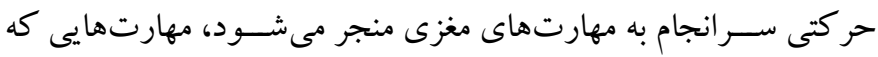

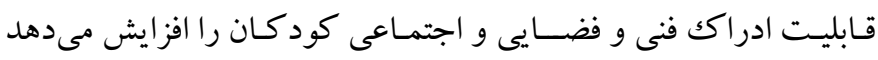

در فرايند تحول، مشكلات كود كان اغلب به علت ناتوانى بزر گسالان

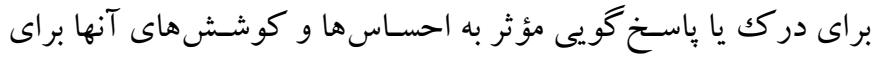

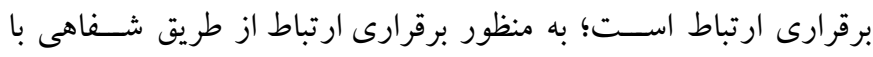

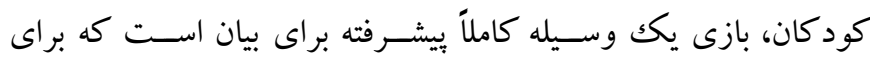

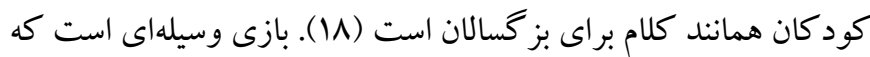
كود كان براى بيان احساسها، برقرارى روابط، توصيف تجربهها، آشكار

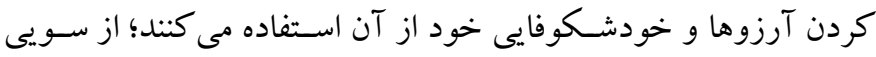

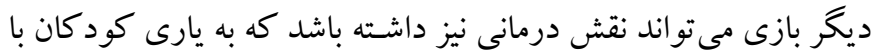

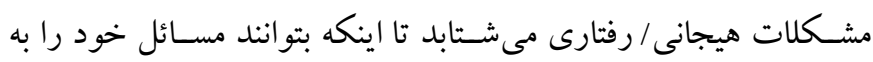
دسـت خويش و از طريق بازىهاى خود حل كنند. در اين روش به به به كود كان فرصـت داده مىشـود تا احسـاس هاى آزاردهنده و مشـكلات

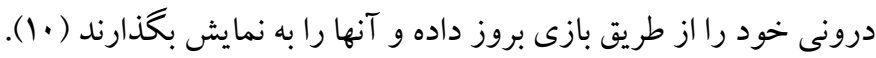
در مورد اهميـت حركتهاى موزون نيز نظريات فر اوانى بيان شـــهـ

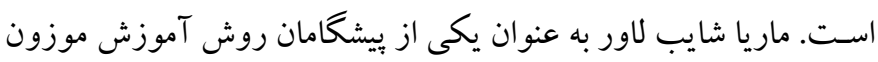
معتقد است كه حركت، دروازهاى است كه از طريق آن مىتوان به درون

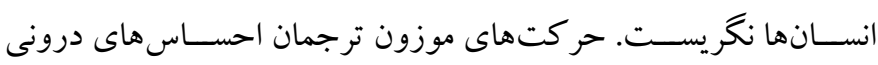
كود ككاند؛ احسـاساتى كه نمى توان آن را بيان كرد و تنها به وسيله انجام اين حركتها قابل وصـف اند (1). از سـويى ديخر به دليل برخو ردارى حر كات موزون از انواع محر ككهاى شـيدارى، ديدارى، لمسى و تأكيد

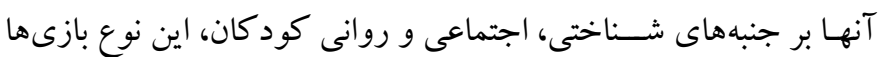
تأثيرات جندجانبهاى را براى كود كان به همراه داشـته و شـــ ايطى را مهيا
يرخاشـخرانه و آسيب به خود، مشكلات معمول در كود كان است. افزون بر آن، اهميت بيشخيرى زودرس وقتى بيشتر آشكار مىشود كه شاهد

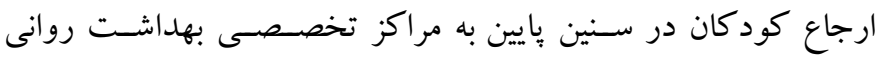

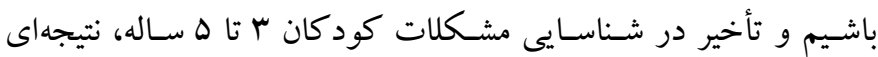
جزء افزايش تأثيرات موقعيت منفى و ايجاد مشـكلات جدى دلى در راه

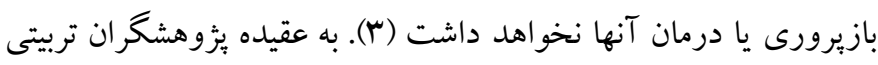
اولين كام در درمان مشكلات و اختلالات رفتارى آكاهى از عواملى مانند

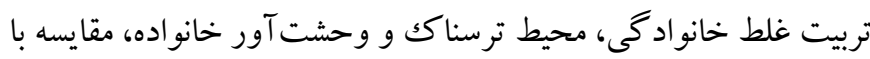

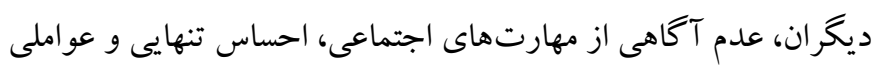
از اين قبيل است كه مطالعات بيشين به اين عوامل اشاره كردهاند (rا). جون در ميان اعضـاى خانواده راه ارتباط با كود كان از طريق كلام كمتر مقدور اسـت و رواندرمانىهاى معمول هم نمىتواند مشـكلات

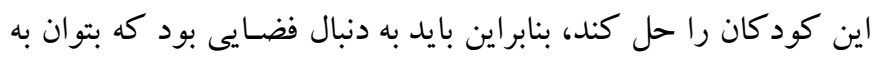
دنياى طبيعى كودكك وارد شـد و مشكلات او را شناسايى و كاهش داد.

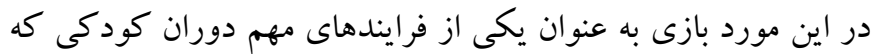

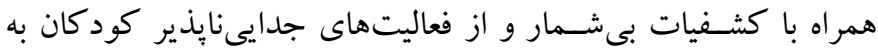

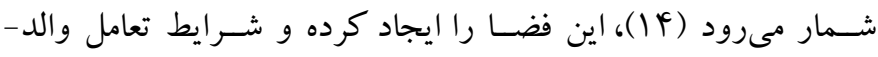

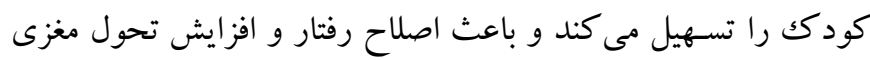
و تخيل مثبت كود كان با مشكلات رفتارى مىشود (ه ().

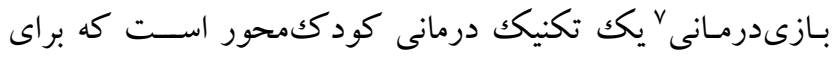

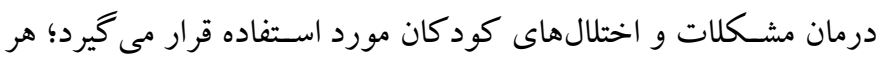
جنـــ كـاربردهـاى بازىدرمانى براى كود كان مشــكلدار در مطالعات

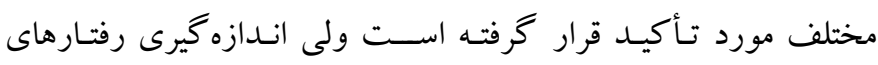

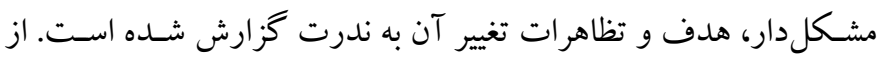

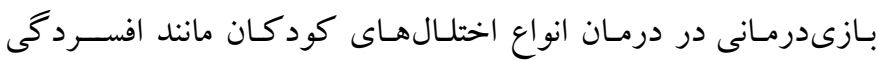

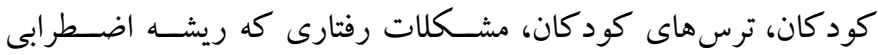

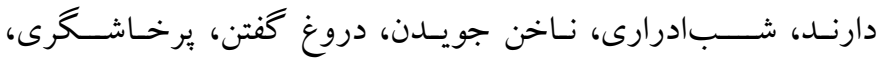

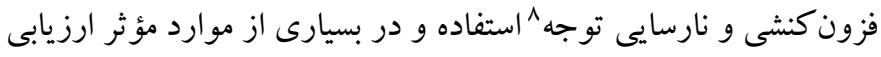

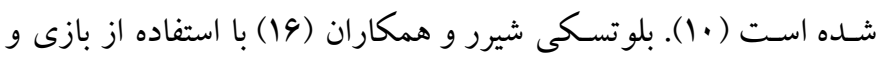

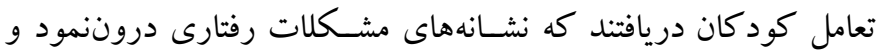

2. Hyperactivity and attention deficit (ADHD) 
مخصوص فرزندان كار كنان و اعضاى هيئت علمى دانشكاه شهيد بهشتى

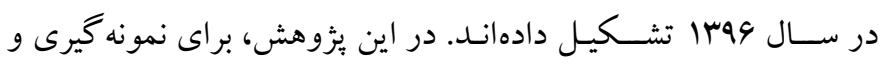

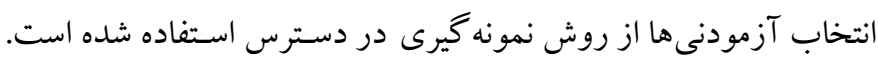

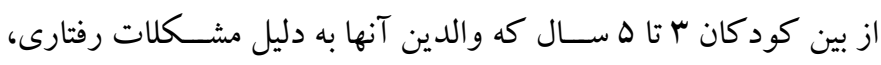

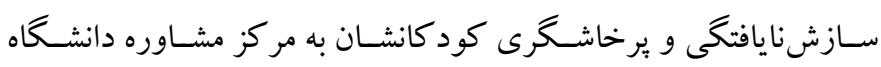

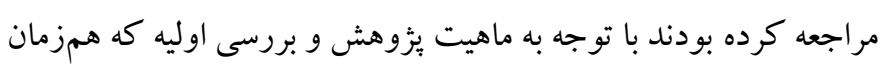

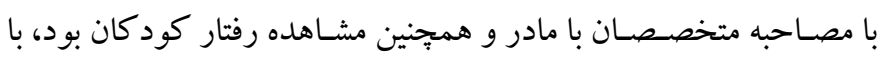

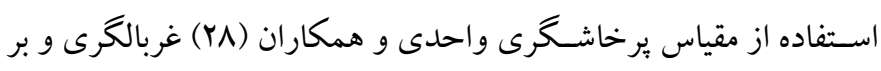

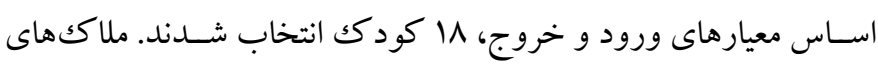

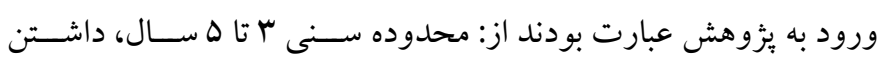

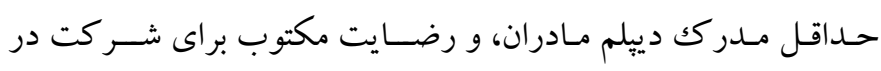

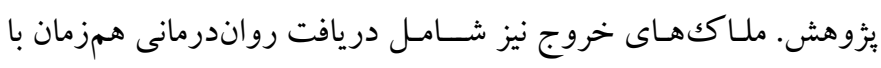

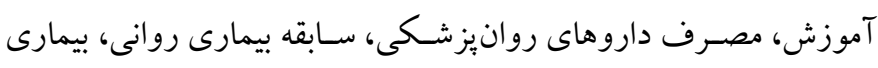

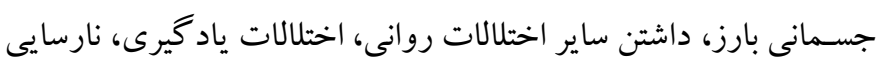

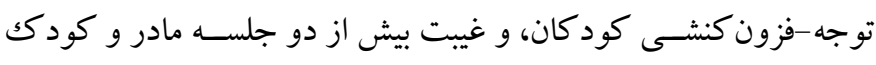

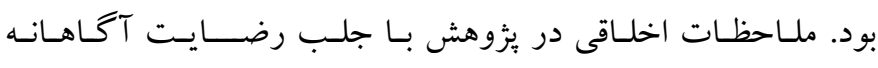

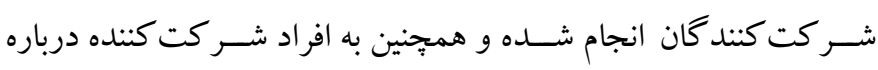

$$
\text { محرمانه بو دن نتايج اطمينان داده شده است. }
$$

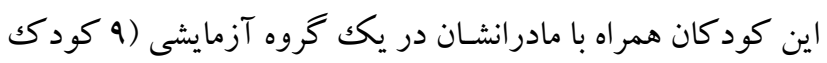

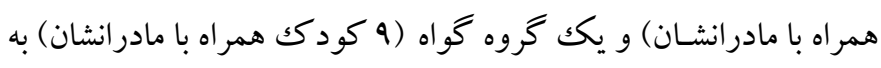
صورت تصـادفى جايدهى شـدند. آزمودنىهاى گرووه آزمايش به مدات

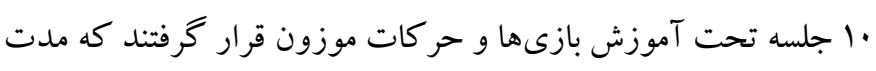

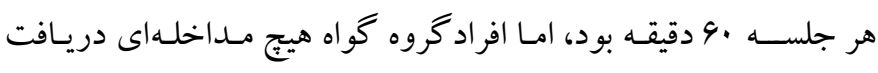

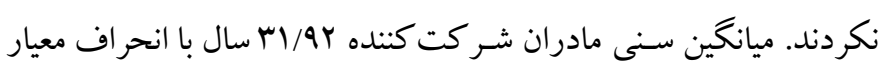

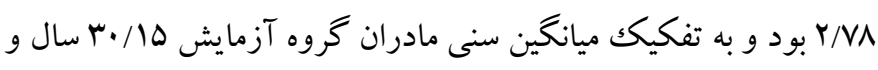

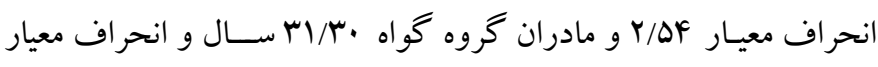

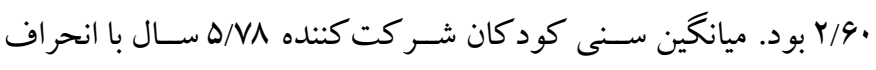

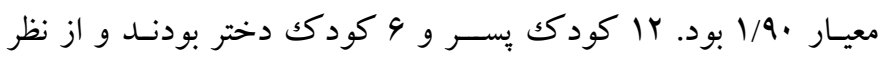
وضعيت اقتصادى همه مادران شر كت كننده در طبقه متوسط قرار داشتند.
مى كنند تا هر كودكى متناسـب با توانيى و استتعدادش از آن بهره گيرد

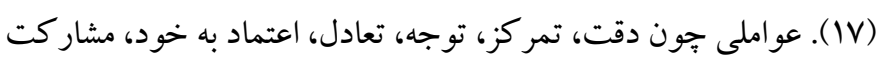

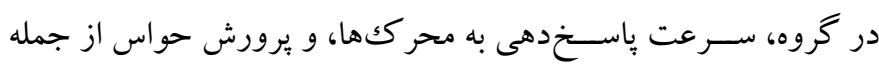
زمينههايى هسـتند كه در حر كتهاى موزون تحول و توســعه مي يابند

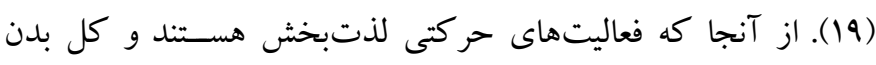

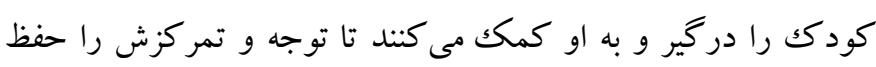

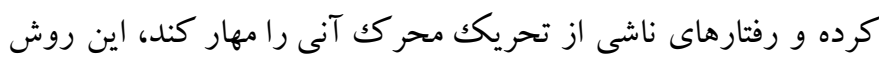

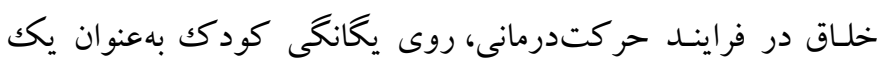

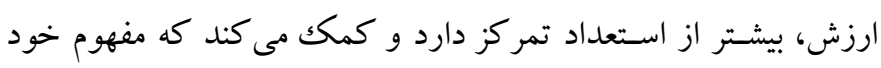
كودك كه به وسيله شكست هاى مكرر آسيبديده است، درمان شود

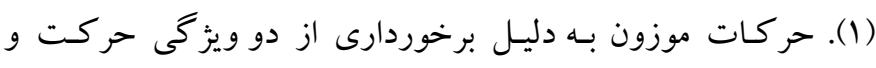

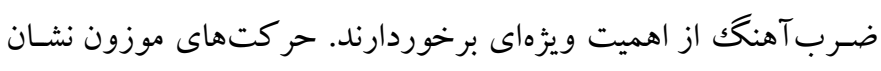
دهنده احساسات درونى كودك هستند؛ احساساتى كه نمىتوان آنها را

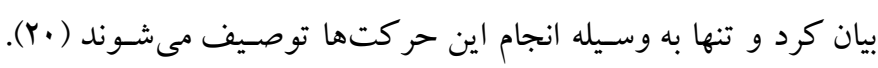

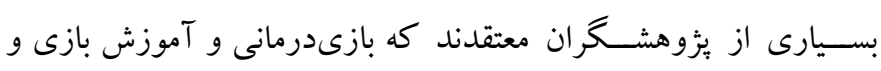

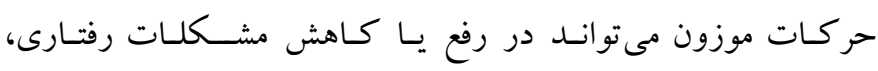

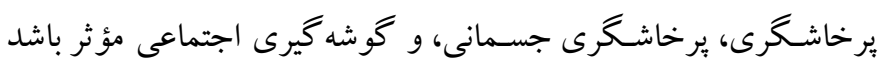

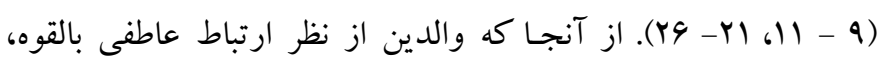

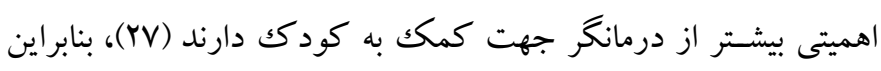

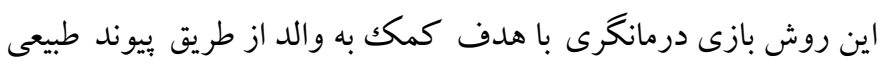

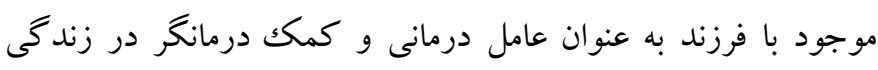

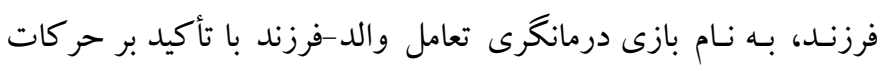

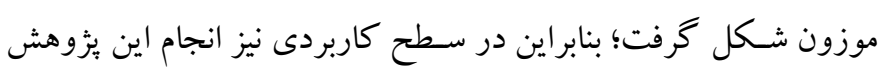

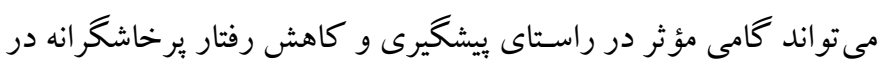

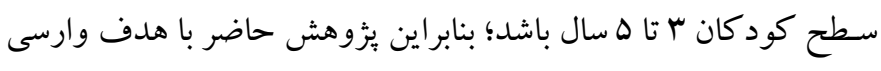

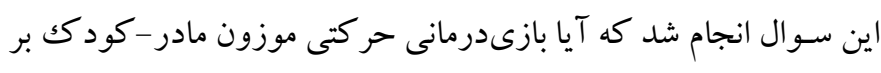
كاهش برخاشگرى كلامى و غير كلامى كود كان ب تا ها سال مؤثر است.

روش) الف) طرح هزوهش و شـــ كت كنند كان: يزٔوهش حاضـر يكك مطالعه

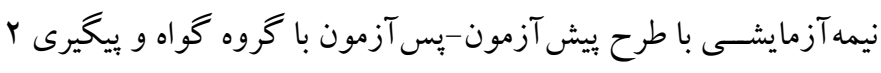

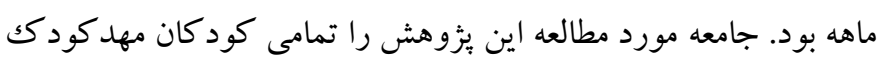


كلامى - تهاجمى، فيزيكى - تهاجمى، رابطهاى و خشــم تكانشـى به

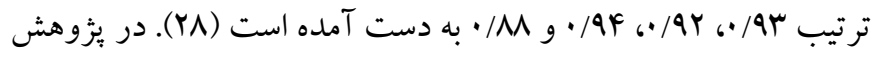
رجب يور و همكاران (9)، ضـريب آلفاى كرونباخ براى زيرمقياسهاى برخـاشــرى كلـامى - تهاجمى، برخاشــرى فيزيكى - تهاجمى،

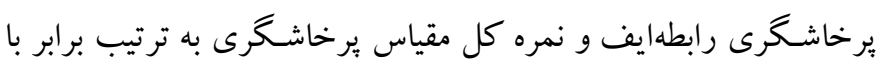
P •/V9 آلفـاى كرونبـاخ براى نمره كـل برابر بـا MN/ • و براى خردهمقياس ها بين

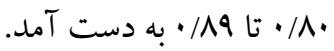

ج) برنـامه مداخله: در اين مطالعه از آموزش بازىها و حر كات موزون براى اجراى مداخله روى كروه آزمايش اسـتفاده شـد. بازىهاى انتخاب شــده براى اين بسـته آموزشــى از كتاب حر كتها و بازىهاى موزون رافعى (IV) انتخاب شـدند. اين بزُوهش در f مرحله انجام شد: ا. مرحله اجـراى مقـدمـاتى آزمون و انتخـاب نمونسهـــاى يثزوهش؛ ب. مرحلـه بيش آزمون؛ ا. مرحله آموزش؛ أ. مرحله يس آزمون و بيگيرى. كود كان كروه آزمايش همراه با مادرانشـان در · ا جلسه •9 دقيقهاى و به صورت كروهى در اتـاق بـازى مهد كودك به صــورت هفتخى دو جلســه در روزهاى يكشــنه و ســهـــنه از سـاعت · الى الى لا تحت بازىدرمانى حر كات موزون قرار كرفتند. در اين يثزوهش ^ بازى موزون با حضسور مادر و كودكك مورد اسـتفاده قرار كفت. در اجراى اين بازىها اصسول تطابقسازى از ساده به مشكل مورد توجه قرار گرفت. متن موسيقىها و اشعار بس از تهيه با تأييد سه نفر از متخصصان با كمكك مربيان مهلها و مدارس بر اساس جدول ا اجرا شد.

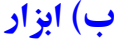
ا. مقياس ثرخاشخرى ": اين مقياس سج سؤالى، براى ارزيابى برخاشخرى جسمانى، رابطهاى و واكنشى - كلامى كود كان است و براى اولين بار در سال INAV توسط واحدى، فتحى آذر، حسينى نسب و مقدم با استفاده از

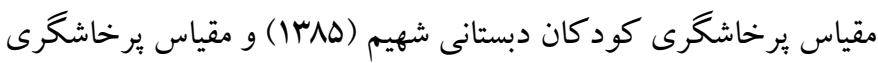
اهواز (IFAF) به منظور سـنجش ابعاد مختلف برخاشـرى در كود كان

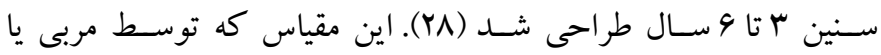
والدين كودكك تكميل مىشود شامل يكك نمره كلى و جهار زيرمقياس الف) يرخاشـخرى كلامى - تهاجمى "'، ب) برخاشــرى فيزيكى -

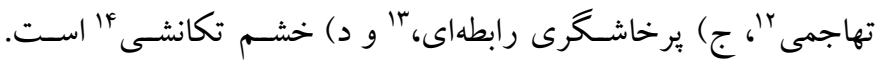
نمرهدهى اين مقياس در يكك مقياس ليكرتى ه درجهاى اصسلاً= . بهندرت =ا، يككبار در ماه = r، يككبار در هفته = س، اغلب روزها F اسـت كه نمره هر زيرمقياس از جمع نمره سؤالهاى مربوطه و نمره كل از جمع تمامى زيرمقياسها به دست مى آيد. نمره اين مقياس مىتواند بين · تـا 191 در نوســان بـاشـــ كـه نمره بالا نشــان دهنده ميزان بالاى يرخاشـكرى در كود كان اسـت. واحدى و همكاران، ضـريب KMO را براى اين مقيـاس برابر بـا هه/ • خزارش كردنسد و همجِنين آزمون كروى

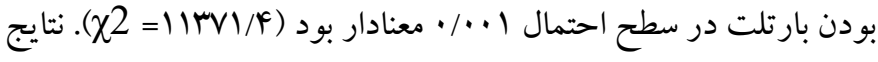
تحليل عاملى حاكى از تأييد روايى سازه اين ابزار بود و ضريب همبستگى

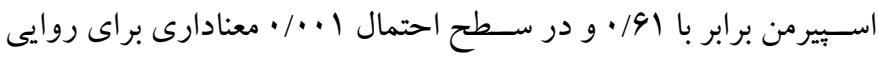
همزمان كزارش شـد. همجينين براى ارزيابى و سـنجش همسـانى درونى، آلفاى كرونباخ در كل مقياس و در عاملهاى جهار كانه يرخاشـكرى

جدول 1: خلاصه جلسات آموزشى بازىدرمانى حركات موزون

\begin{tabular}{|c|c|c|}
\hline محتوا & اهداف & جلسات \\
\hline 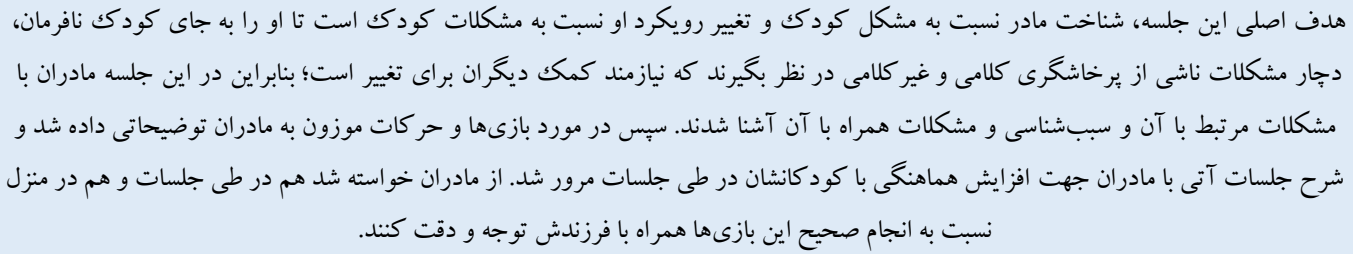 & آشنايى & يكم \\
\hline
\end{tabular}

3. Relationship aggression

4. Impulsive anger
1. Aggression scale

1. Verbal-aggressive aggression

2. Physical-aggressive aggression 
در اين بازى كودكك بايد بر روى خط راست با توجه به ضربآهنگك موسيقى بدود و دستورات ارائه شده در متن موسيقى (يريدن، نشستن، ليلى

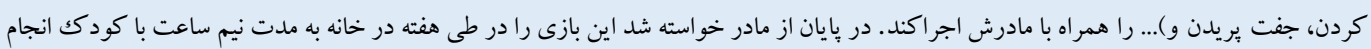

بازى خط موزيكال

دهد.

كودكك مىبايست روى لوزى كه با خطوط رنخى متفاوت طراحى شده بر اساس الخوى مربى همراه با موسيقى حركت كند. اين حركت در ابتدا

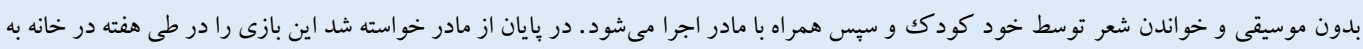
مدت نيم ساعت با كودك انجام دهد.

در اين بازى كود كان در محيط با توجه به صداهاى بخش شده شكل صدا را به كمك مادر به نمايش مى گذارند. براى مثال با شنيدن صداى

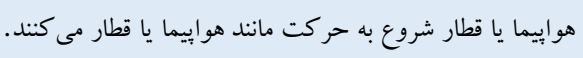

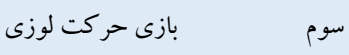
جهارم

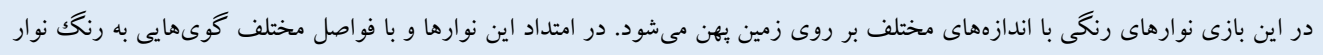

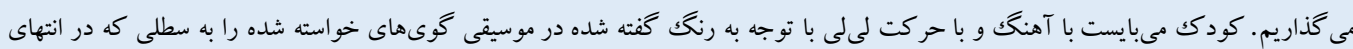

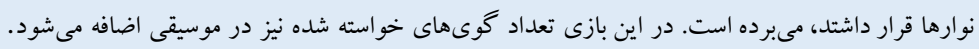

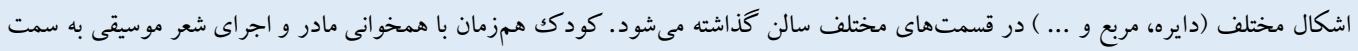

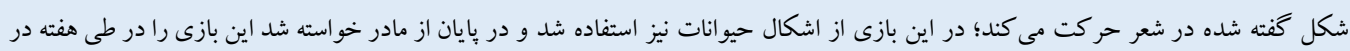
خانه به مدت نيم ساعت با كود كك انجام دهد.

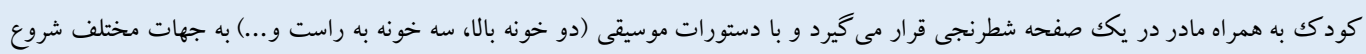

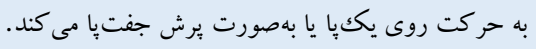

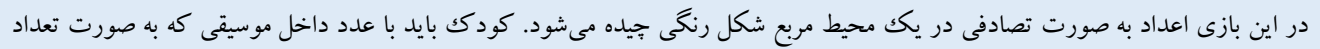

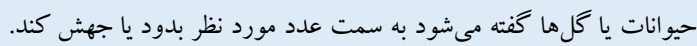

ينجم

بازي ميدان اشكال

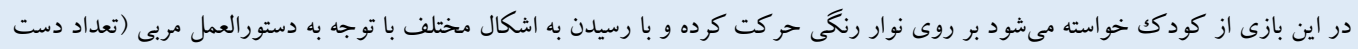

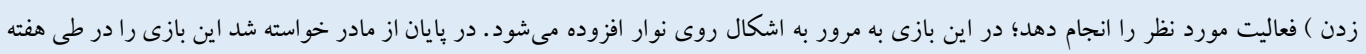
بازى اشكال نوارى نهم در خانه به مدت نيم ساعت با كودك انجام دهد.

هدف اين جلسه مجموع گزارشهاى مادران در مورد بازى با فرزند خود در منزل و بحث و تبادل نظر در مورد نقاط قوت هر يكك اند از تمرينها

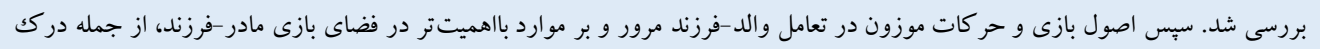

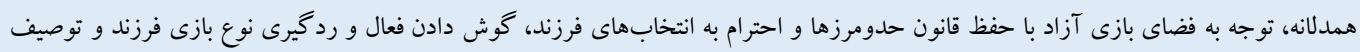
جمعبندى בתד

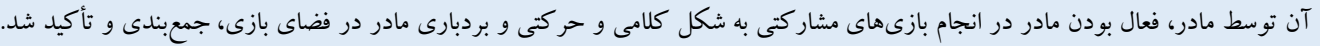

\section{يافتهها}

يافته اصلى يُزوهش كه بر اساس نمرات براشخاشكرى و آزمون تحليل

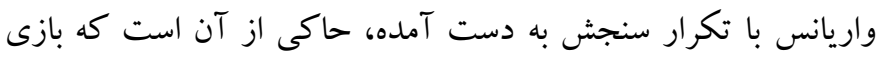

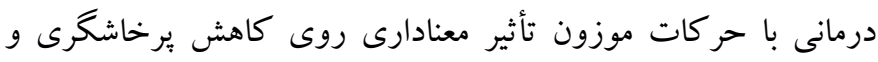

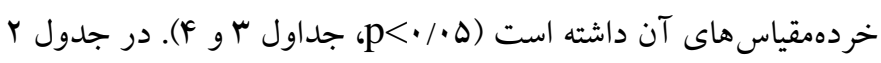
شاخصهاى توصيفى برخاشخرى و خردهمقياسهاى آن، شامل ميانگين

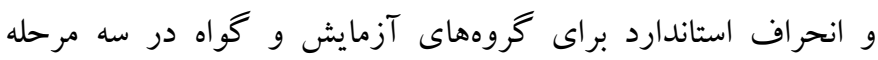

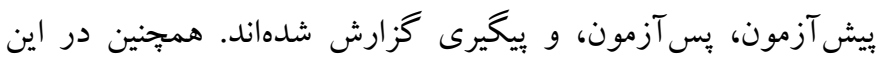

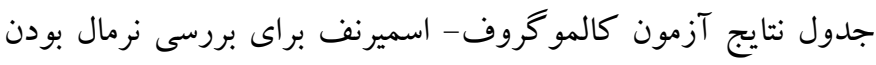
توزيع دادهها ارائه شدهاند.
د) شـيوه اجرا: بعد از كسـب مجوز از مركز مشـاوره دانشـكاه شـهيد

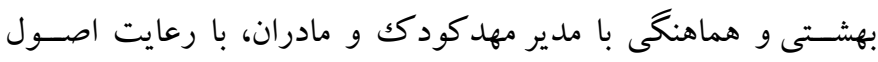

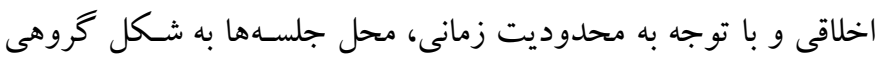
در اتاق بازى مهدكودكى كه از لحاظ محيط، فضـا و تجهيزات مناسـب

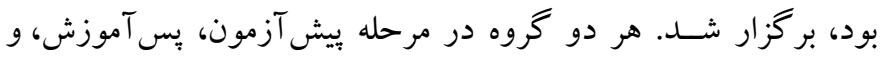

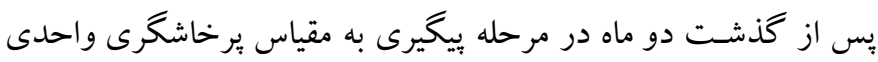

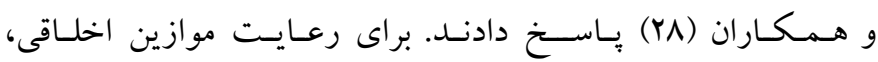

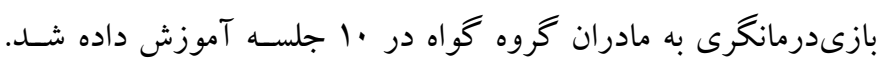

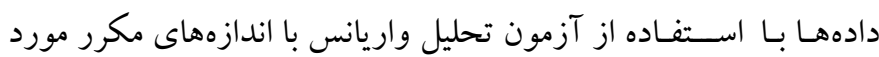
تجزيه و تحليل قرار گرفت. 
جدول r: شاخصهاى توصيفى متغيرهاى يزوهش براى كروه آزمايش و كواه در سه مرحله بيش آزمون، يس آزمون، و ييكيرى

\begin{tabular}{|c|c|c|c|c|c|c|c|c|c|}
\hline \multicolumn{2}{|c|}{ كالموكروف-اسميرنف } & \multicolumn{2}{|c|}{ بيغيرى } & \multicolumn{2}{|c|}{ يس آزمون } & \multicolumn{2}{|c|}{ بيش آزمون } & \multicolumn{2}{|c|}{ شاخصهاى آمارى } \\
\hline سطح معنادارى & آماره K-S Z & انحراف معيار & ميانكين & انحراف معيار & ميانكين & انحراف معيار & ميانكين & كروه & متغير \\
\hline$\cdot / \Lambda$ & . $/ 4 r$ & $9 / 19$ & $111 / \pi r$ & $\Delta / Y F$ & $11 Y / \Delta 4$ & $4 / 94$ & $\mid r \Delta / F F$ & آزمايش & \\
\hline$\cdot / r$. &.$/ 10$ & $9 / 1 F$ & Irg/FF & $V / \& \Lambda$ & $\mid r V / 9 V$ & g/Dr & IrG/NT & كواه & \\
\hline.$/ 19$ & $\cdot / T V$ & ו ו & $r F / M \mu$ & $r / 9 Y$ & $M F / \Delta Q$ & r/AT & $r q / r r$ & آزمايش & \\
\hline$\cdot / \cdot v$ & $\cdot / r V$ & $r / 9 T$ & Fr/VA & $r / \wedge q$ & $\mathrm{kr} / \mathrm{ll}$ & $r / 94$ & $\kappa r / \wedge q$ & كواه & \\
\hline$\cdot / r$. & $\cdot / I V$ & $r / 19$ & MG/Yr & 1/99 & $\mathrm{rV} / \mathrm{II}$ & $1 / 9$. & $\kappa \mu / 11$ & آزمايش & \\
\hline$\cdot / \cdot \wedge$ & $\cdot / T \Delta$ & $1 / V^{F}$ & $F Y / F F$ & $1 / r \pi$ & FT/DG & $1 / N r$ & $\kappa \mu / .$. & كواه & \\
\hline.$/ .9$ & $\cdot / r r$ & $1 / 9 r$ & rT/rY & $1 / \pi q$ & rr/Yr & $1 / \pi$ & TA/TY & آزمايش & \\
\hline .119 & $\cdot / r$. & $r / T r$ & $r V / T V$ & $r / \Delta$. & rVIFF & 1/9F & TV/DG & كواه & \\
\hline.$/ 1 \wedge$ & $\cdot / r$ & $1 / 41$ & $\mathrm{IV} / \cdot \mathrm{r}$ & $1 / \mathrm{VA}$ & $19 / \mathrm{NA}$ & $1 / 4 Y$ & $r \mid / F F$ & آزمايش & \\
\hline$\cdot / r$. & $\cdot / 10$ & $1 / \Delta \Lambda$ & $r \cdot / \cdot \cdot$ & $1 / 99$ & $19 / 19$ & $1 / \Delta$. & $r \cdot 109$ & كواه & \\
\hline
\end{tabular}

براى بررسى فرضيه هاى بثوهش از تحليل واريانس با تكرار سنجش

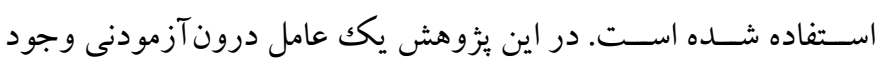
داشـت كه آن عضـويت گروهى بود؛ بنابراين طرح مورد اسـتفاده طرح درون- بين آزمودنى اسـت. در اين بخش نتايج آزمون تحليل واريانس با تكرار سـنجش براى كروهها ارائه مىشـود، سـبس در بخش بعد فرضسيه مطرح شـده يزٔوهش با اسـتفاده از مقايسـهاى زوجى كروهها يُاسخ داده مىشــود. در جـدول س نتـايج آزمون موجلى جهـت بررسـى كرويــت متغير هاى بزٔوهش خزارش شده است.
با توجه به جدول Y، آماره Z آزمون كولمو گراف- اســميرنف براى يرخـاشـــرى كلى و خردهمقيـاس هـاى آن و در تمامى گرووهها معنادار نيســـ؛ بنـابر اين توزيع تمـامى متغيرها نرمال اســت. همجِين يافتهاى جـدول فوق نشــان مىدهد كه در متغيرهاى يثزوهش ميانخين گرووهاى آزمايش از بيش آزمون تا يس آزمون و بس از گذشــته دو ماه در مرحله ييخيرى كـاهش يافته اســت؛ اما ميانگين گروه كو اه در اين مراحل تغيير محسوسى بيدا نكرده است.

جدول "ז: نتايج آزمون موجلى متغير ها

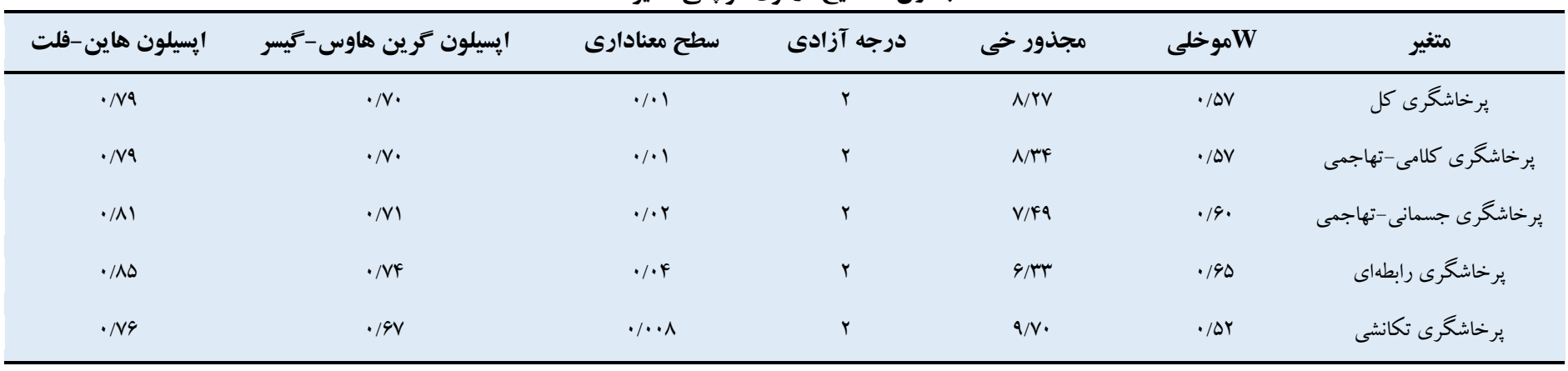


افزايش دقـت آمـاره F، درجـه آزادى را بـا اســففاده از دو روش گرين

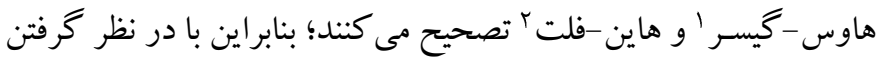

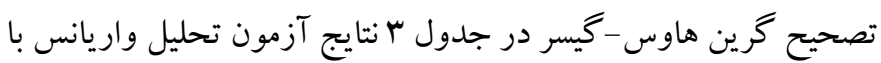

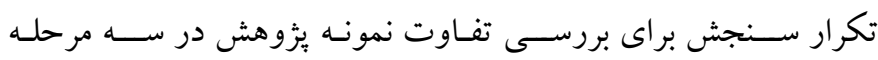

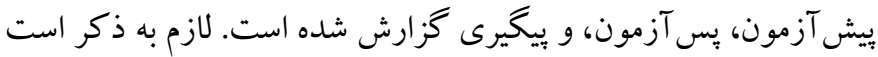

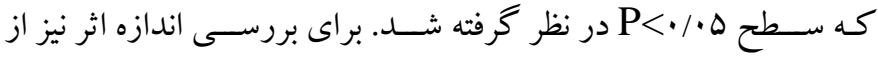
مجذور اتاى جزئى ب استفاده شد.
نتـايج جدول ץ نشـان مىدهد كه آماره W موجلى براى متغيرهاى

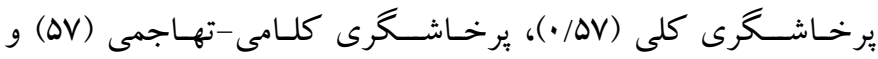

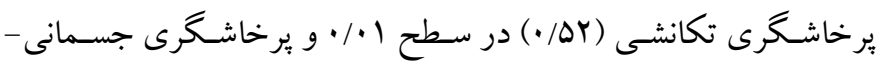

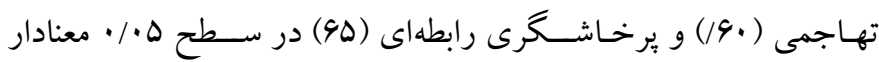

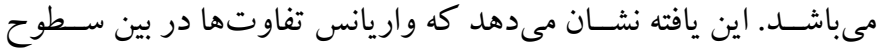
متغير وابسـته به صــورت معنادارى متفاوت اســ؛؛ بنابر اين بيشفرض

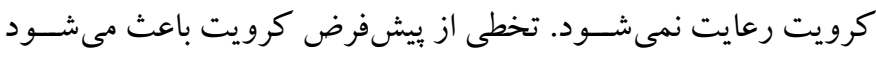

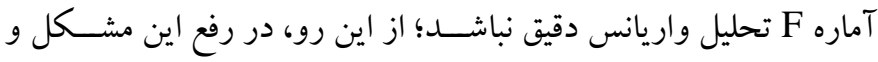

جدول ع: نتايج آزمون تحليل واريانس براى بررسى تفاوت كروهها در سه متغيرهاى ثزوهش

\begin{tabular}{|c|c|c|c|c|c|c|c|c|}
\hline توان آزمون & اندازه اثر & سطح معنادارى & $\mathbf{F}$ & ميانكين مجذورات & درجه آزادى & مجموع مجذورات & منبع تغييرات & متغير \\
\hline $1 / \cdots$ & $\cdot|\wedge|$ & $\cdot / \cdots$ & $V Y / \Delta \Delta$ & $V Y / \Delta \Delta$ & $|/| q \mid$ & $r \mid V / \ldots$ & حلهى ارزيابى & \multirow{3}{*}{ نمره كل } \\
\hline $1 / \cdots$ & $\cdot / \mathrm{Vq}$ & $\cdot / \cdots$ & $91 / 9$. & Ir./V9 & $|/ 4|$ & $M \Delta \Delta / \backslash F$ & تعامل ارزيابى ** گروه & \\
\hline$\cdot 191$ & $\cdot / 49$ & $\cdot / \cdot r$ & $9 / 91$ & $199 / 49$ & 1 & $199 / 49$ & كروه & \\
\hline$\cdot / 99$ & $\cdot / \Delta 9$ & $\cdot / \cdots$ & $r \mid / \cdot r$ & $\mathrm{Fr} / \mathrm{FV}$ & $1 / \mu \cdot$ & $\Delta 9 / V V$ & \multirow{3}{*}{ 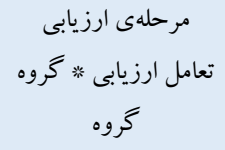 } & \multirow{3}{*}{ مى -تهاشخىى } \\
\hline$\cdot / 99$ & $\cdot / \Delta 1$ & $\cdot / \cdots$ & $19 / 1 \mid$ & $M F / V T$ & $1 / \Gamma \cdot$ & $F Q / T V$ & & \\
\hline$\cdot 199$ & $\cdot / \Delta$ & $\cdot 1 \cdots 1$ & $19 / 09$ & $r r \cdot / \cdot 1$ & 1 & $r r \cdot / \cdot 1$ & & \\
\hline $1 / \cdots$ & •/Ar & $\cdot / \cdots$ & $V M / T F$ & $\Lambda \cdot / \cdot \Delta$ & $1 / 19$ & $9 \pi / \cdot r$ & \multirow{3}{*}{ 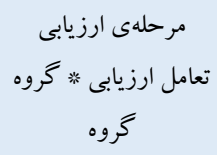 } & \multirow{2}{*}{ رسماشكُى } \\
\hline $1 / \cdots$ & ./V9 & $\cdot / \cdots$ & $\Delta 1 / \Delta$ & $\Delta \varphi / Y I$ & $1 / 19$ & ת & & \\
\hline$\cdot / 9 F$ & $\cdot / F V$ & $\cdot / r$ & $1 F / 19$ & $11 r / 94$ & 1 & $11 r / 99$ & & تهاجمى \\
\hline $1 / \cdots$ & $\cdot / \Delta \varphi$ & $\cdot / \cdots$ & $r \cdot / F r$ & YY/FF & $1 / 91$ & $\mathrm{Fr} / \mathrm{Qr}$ & مرحلهى ارزيابى & \multirow{3}{*}{ رخاشگرى } \\
\hline$\cdot / 9 F$ & • & $\cdot / \cdots 1$ & $1 / 91$ & $9 / F V$ & $1 / 91$ & $|1 / 1|$ & تعامل ارزيابى ** گروه & \\
\hline$\cdot / 99$ & $\cdot / \Delta \Lambda$ & $\cdot / \cdots$ & rr/TMG & $4 \cdot 119$ & 1 & $4 \cdot 119$ & كروه & \\
\hline $1 / \cdots$ & $\cdot / A F$ & $\cdot / \cdots$ & $\wedge \Delta / v$ & $1 \cdot 1 / r^{q}$ & $1 / \cdot V$ & $119 / \mathrm{TD}$ & مرحله ارزيابى & \multirow{3}{*}{ تخاشخرى } \\
\hline $1 / \cdots$ & •/A &.$\cdots$ & $\Lambda Y / \Delta Q$ & $1 \cdot F / F \Delta$ & $1 / \cdot V$ & $11 r / r$ & تعامل ارزيابى ** گروه & \\
\hline$\cdot 149$ & $\cdot / 19$ & .1 .9 & $r / 9 V$ & $\Delta \Lambda / \cdot V$ & 1 & $\Delta \Lambda / \cdot V$ & كروه & \\
\hline
\end{tabular}

يرخاشــرى كلى و خردهمقياسهاى آن بيشـتر از • 1/ • ات كه نشــان مىدهد تفاوت بين گروهها در جامعه بزرگك و قابل توجه است. همجينين جهت بررسـى تفاوت كروه بازىدرمانى حر كات موزون با گروه گ اه در متغيرهاى بثزوهش در جدول ه نتايج مقايسه ميانكين كروه آزمـايش و كواه در ســـهه مرحلـه يِيش آزمون، يس آزمون، و يِيخيرى كزارش شده است.
بر اســاس نتـايج جـدول Fا، ميزان F اثر تعامل ارزيابى و گروهه براى

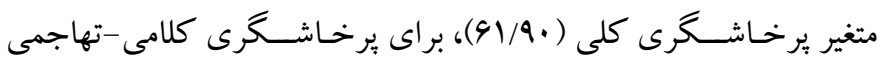

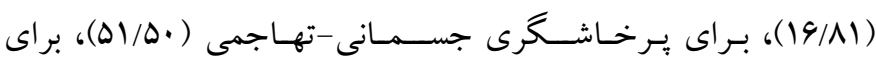

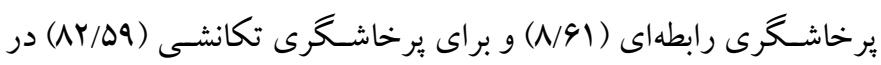
سطح 1 + · • معنادار است. اين يافته نشان مىدهد كه كروههاى آزمايش و گو اه از لحاظ متغير هاى يزٔوهش در سه مرحله بيش آزمون، يس آزمون، و ييكيرى بـا يكـديكر تفـاوت معنـادارى دارند. همجنين مجذور اتا براى 


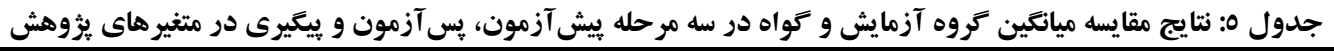

\begin{tabular}{|c|c|c|c|c|}
\hline سطح معنادارى & خطاى استاندارد بر آورد & تفاوت ميانكين كروه آزمايش با كواه & مرحله & متغير \\
\hline$\cdot / \cdot 1$ &.$/ 0$. & $1 / Y Y$ & بيش آزمون & \\
\hline$\cdot \cdots$ & .190 & $\Delta / V V$ & 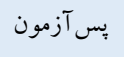 & يرخاشگرى كلى \\
\hline$\cdot \cdots$ & $\cdot / 19$ & $\mathrm{v} / \cdot \cdot$ & ييخيرى & \\
\hline$\cdot / 19$ & $\cdot / 49$ & $\cdot / r V$ & 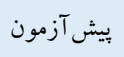 & \\
\hline$\cdot \cdots$ & $\cdot / \Delta F$ & $\Delta / r r$ & يس آزمون & يرخاشكرى كلامى-تهاجمى \\
\hline$\cdot \cdots$ & $\cdot / \Delta 9$ & $\Delta / \Delta$ & ييخيرى & \\
\hline$\cdot /$ fF & $\cdot / r$ & $\cdot / \Delta$ & بيش آزمون & \\
\hline$\% \cdots$ & $\cdot / \mu r$ & r/rY & 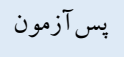 & يرخاشكرى جسمانى -تهاجمى \\
\hline$\cdot \cdots$ & $\cdot / 4 r$ & $r / v r$ & بيخيرى & \\
\hline$\cdot / 94$ & $\cdot / r 1$ & $\cdot / \cdot r$ & ي بيش آزمون & \\
\hline$\cdot \cdots$ & $\cdot / Y_{1}$ & $r / \Delta \Delta$ & 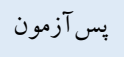 & برخاشخرى رابطهاى \\
\hline$\cdot / \cdots$ & $\cdot / r v$ & $r / \Delta Q$ & ييكيرى & \\
\hline$\cdot / 91$ & $\cdot / r r$ & $\cdot 119$ & يِ آزمون & \\
\hline$\cdot / \cdots$ & $\cdot / 4 \Delta$ & $r / 94$ & يس آزمون & برخاشگ \\
\hline$\cdot \cdots$ & $\cdot / A V$ & $r / \Delta$. & ييخيرى & \\
\hline
\end{tabular}

( + • • معنادار نيست و نشـان مىدهد بين دو گروه تفاوت وجود ندارد؛

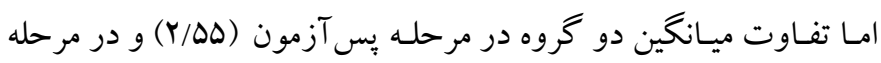

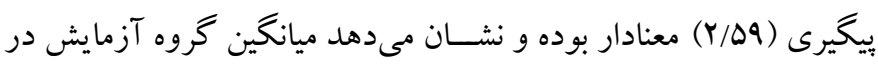
اين دو مرحله به صـورت معنادارى بيشتر از گروه گواه است و در نهايت در خردهمقياس برخاشـكرى تكانشـى تفاوت ميانگين گرووه آزمايش با كروه گو اه در مرحله ييش آزمون (19/•) معنادار نبوده و نشــان مىدهد بين دو گروه تفـاوت وجود نــارد. تفـاوت ميـانخين دو گرووه در مرحلـه

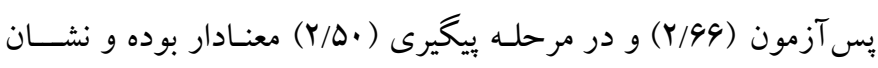
مىدهـد ميانكين گروه آزمايش در اين دو مرحله به صــورت معنادارى بيشـتر از گروه كو اه اسـت؛ بنابر اين با توجه به يافتههاى يثزوهش مى توان كفـت كـه بـازىدرمـانى حركات موزون بر كاهش ميزان يرخاشــرى كود كان اثر مثبت و معنادارى دارد.

\section{بحث و نتيجه كيرى}

مطالعه حاضر با هدف تعيين ميزان اثربخشى آموزش بازىهاى حر كتى

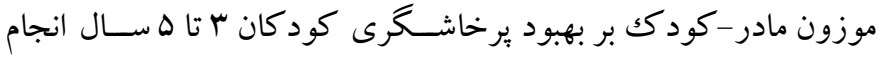

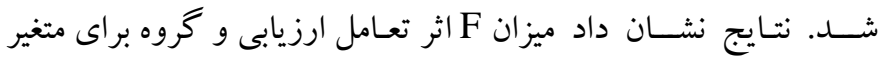

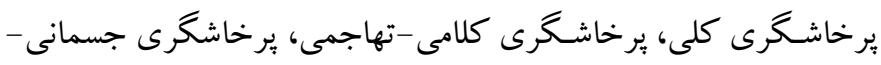

با توجه به جدول هادر متغير برخاشـخرى كلى تفاوت ميانگين گروه

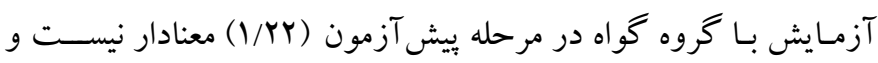

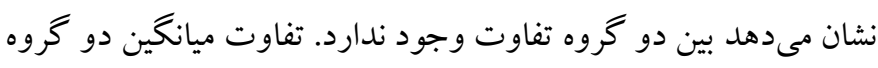

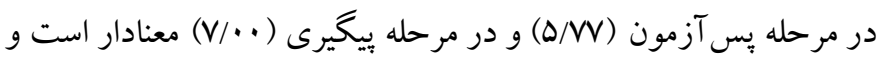

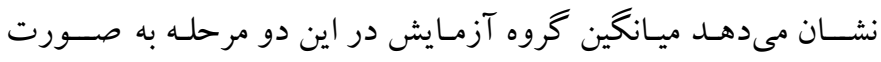

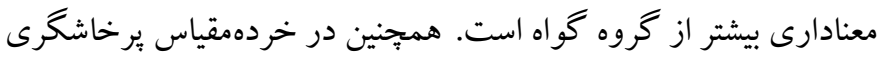

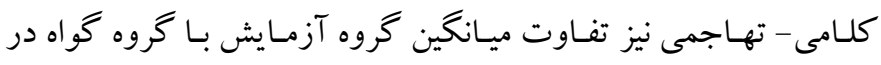

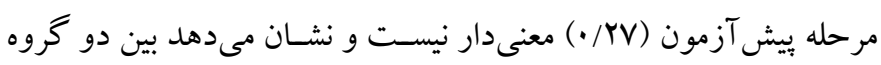

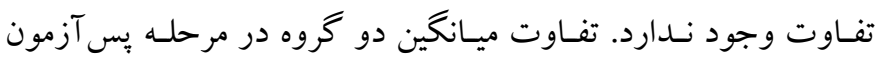

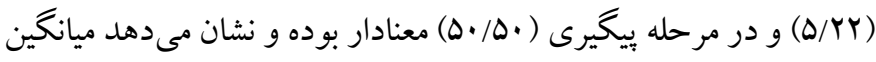
كروه آزمايش در اين دو مرحله به صورت معنادارى بيشتر از خروه گمواه اسـت. در خردممقياس برخاشـخرى جســمانى -تهاجمى تفاوت ميانخين كروه آزمايش با گروه گواه در مرحله بيش آزمون ( •ه/•) معنادار نبودها

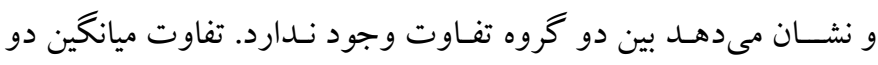

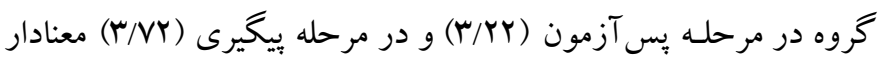

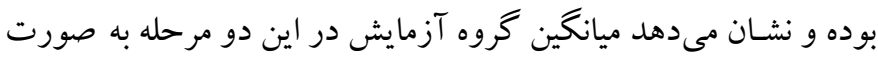

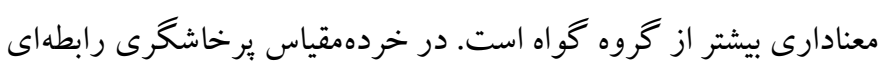

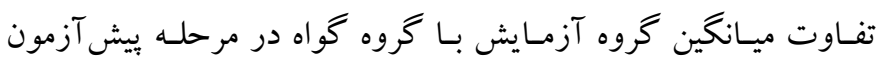


تهديد اســ؛ وقتى كودكك فزون كنش خود را محكوم به بديدههاى

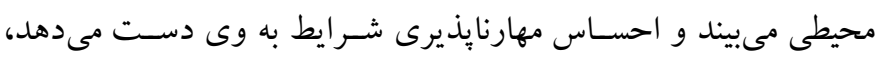

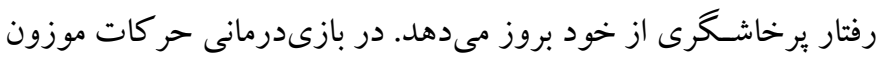

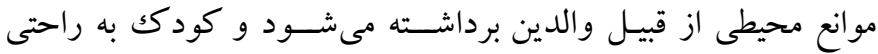

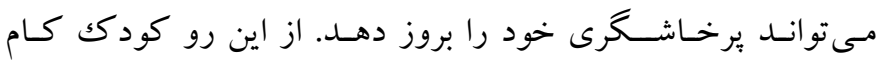

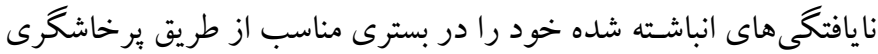

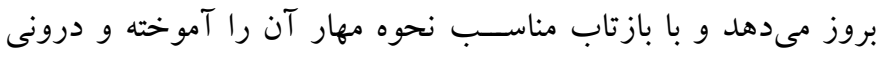

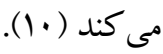

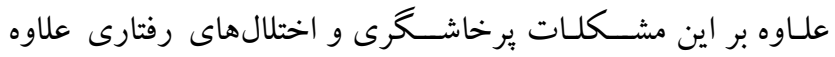
بر اينكه ريشه در اضطر اب كود كان دارند، بلكه همجنين بايد توجه داشت

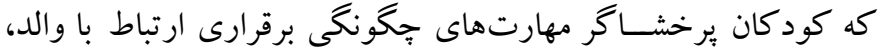
همبازىها و همسـالان خود را نياموخته، يا به گگنهاى ناصسحيح با آنان

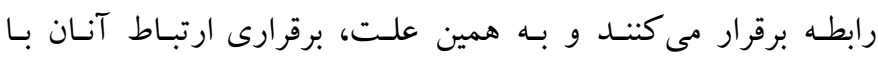
باسـخ هاى مثبت همراه نمىشـود و ممكن اسـت كه از جمع همسالان و

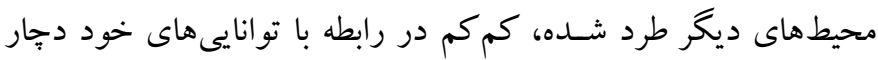
شـكك و ترديد شـوند و به جاى ارتباط صسحيح، عدم برقرارى ارتباط،

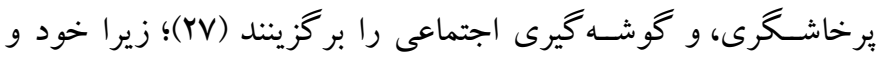

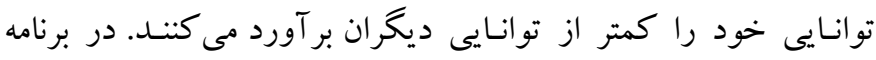

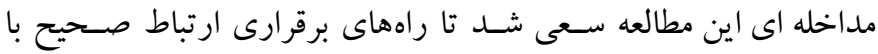

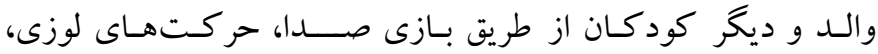

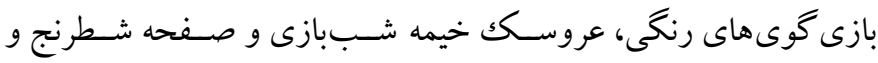

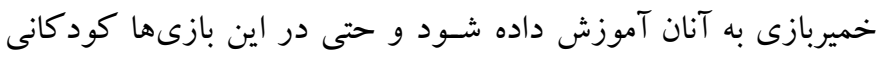

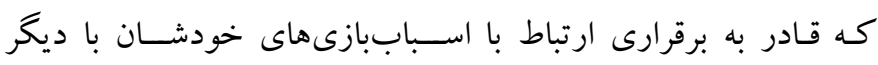

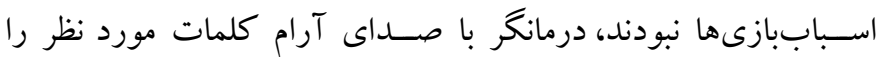

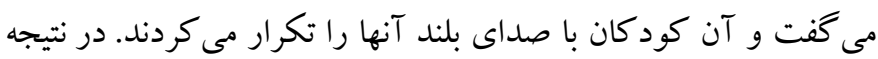
كود كان مجبور به برقرارى ارتباط با والد و همسـالان خود و شركت در

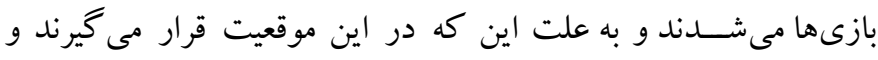

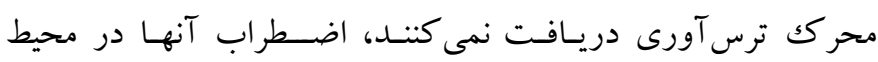
رفتهرفته كمتر مىشد. در طى اين فرايند بعد از مدتى كه كود كان متوجه

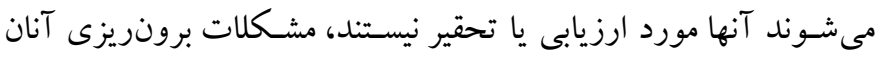
نيز به تدريج برطرف شده و از شركت در بازى با مادر و ساير همسالان

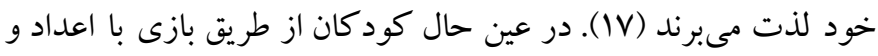

تهاجمى، يرخاشـخرى رابطهاى، و براى يرخاشـخرى تكانشسى در سـطح

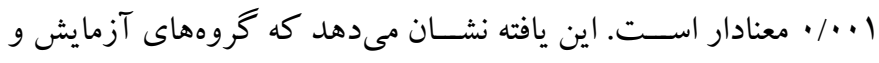

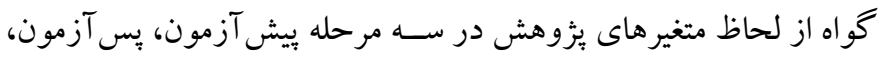

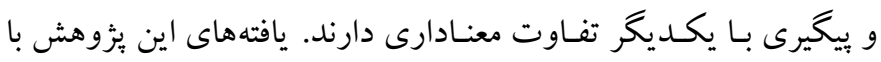

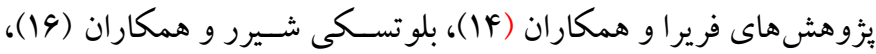

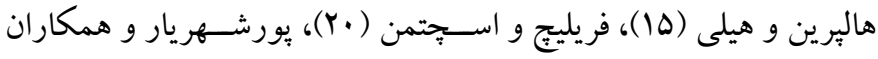

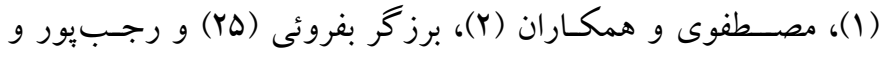

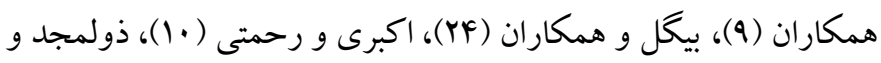

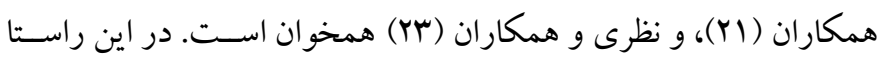

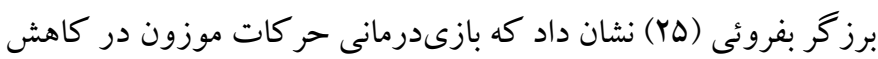

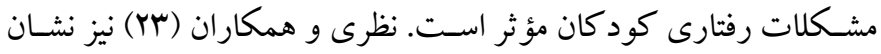
دادند كه تر كيب موسيقى و حر كات موزون بر كاهش مشكلات رفتارى

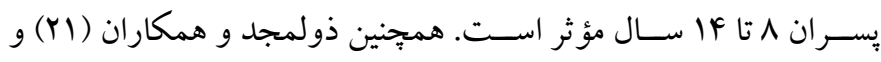
خدابخشى كولايى و همكاران (Yr) نشان دادند كه بازى همرمانى حر كات

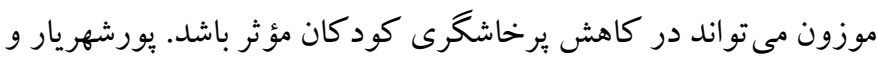

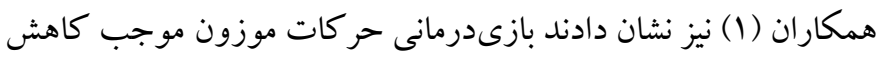

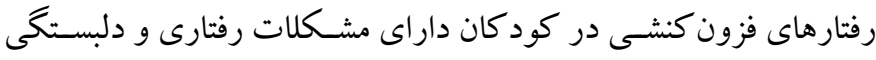
نايمن مى شـود. همجنين اكبرى و رحمتى نيز نشـان دادند بازىدرمانى با روى آورد شـناختىرفتارى در كاهش برخ خاشـخرى كود كان مؤثر اسـت.

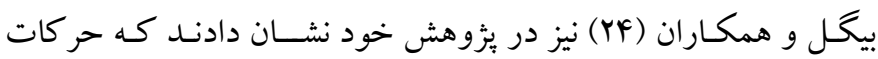

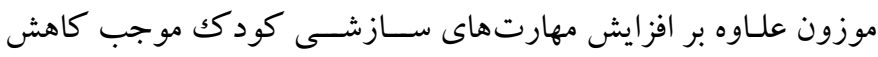
رفتارهاى سازشنايافته و برخاشخرى كود كك مى شود. نتايج اين مطالعات به نوعى با نتايج اين مطالعه همسو هستند.

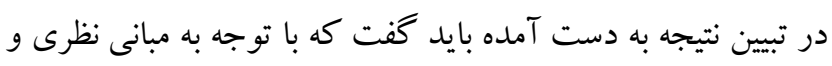

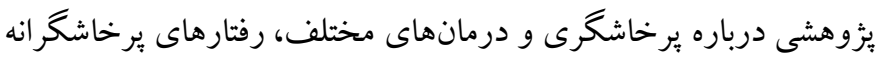

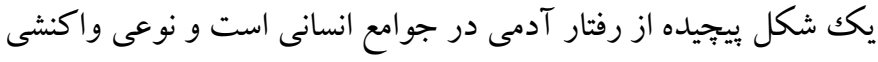

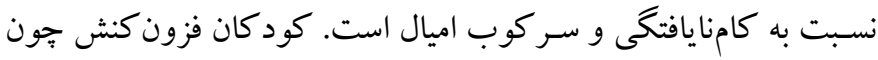

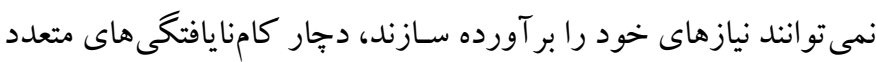

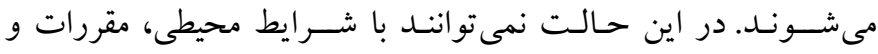
محدوديتهاى جامعه، آداب و رسـوم، ارزشها، و امر و نهىها خود را

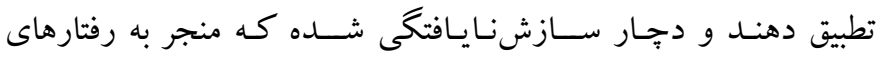
يرخاشـخرى مىشـود. يرخاشـخرى نوعى واكنش نسبت به موانع و عامل 
كود كان با سـنين دوره بيشدبستانى و دبستانى نيز انجام شود. با توجه به

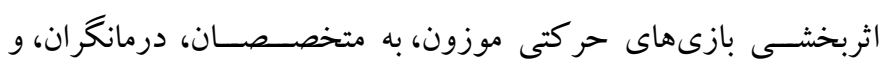

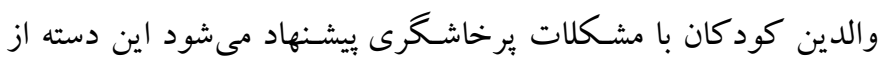

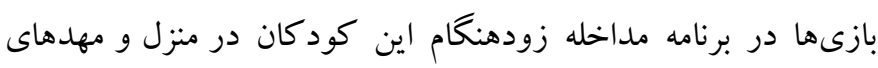

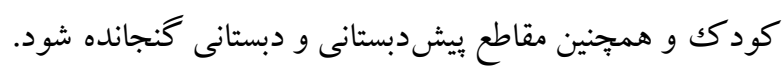

\section{ملاحظات اخلاقى}

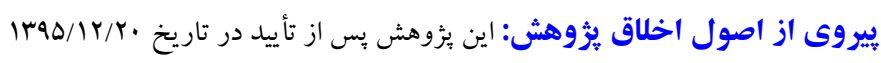

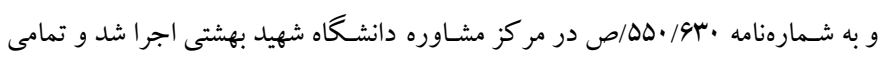

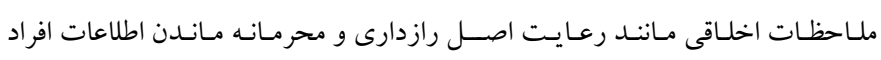

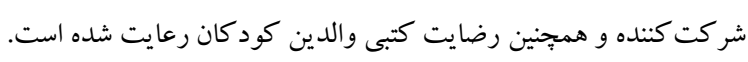

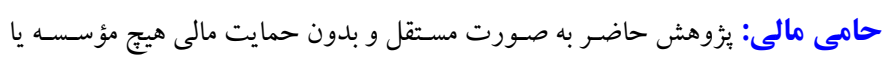
سازمان دولتى يا خصوصى انجام شده است.

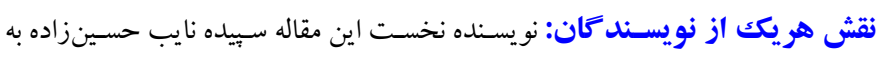
عنوان مجرى يُزوهش و تحليل و تـدوين مقاله؛ نويســنده دوم على آقازيارتى به عنوان

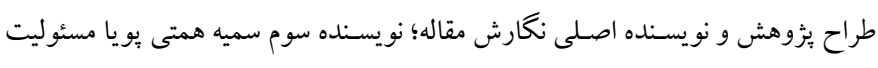

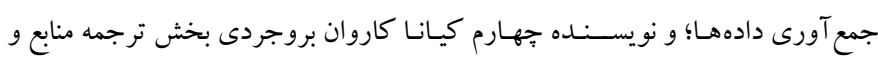
ويراستار علمى را انجام دادهاند. تضـاد منافع: بر اسـاس اعلام نويسند كان، در اين يزٔوهش هيج كونه تضاد منافع وجود نداشته است.

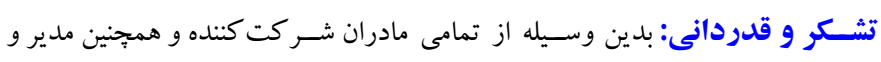

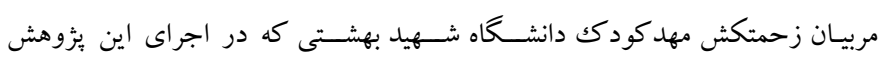
همكارى صميمانهاى داشتند، تشكر و قدردانى شود.
رنكُها و عروسـك هاى خيمه شـب بازى، مهارتهاى اجتماعى مناسـب

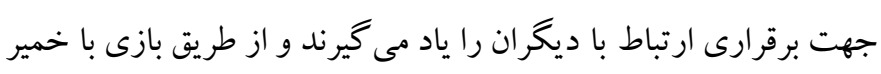

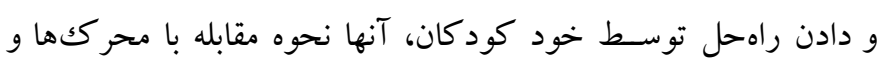

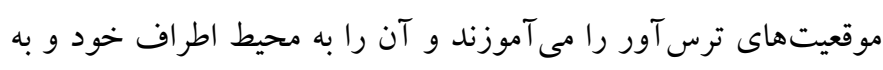
خصوص در ارتباط با همسالان تعميم مى هـندئ.

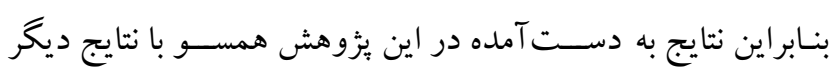

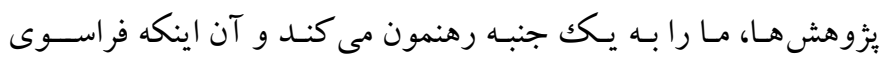

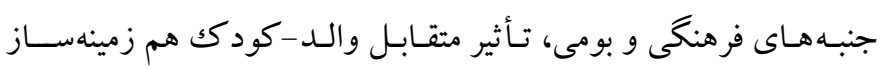

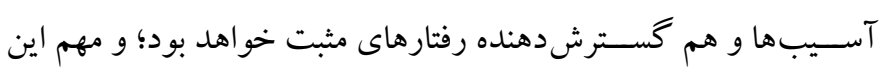

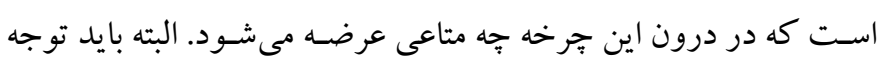

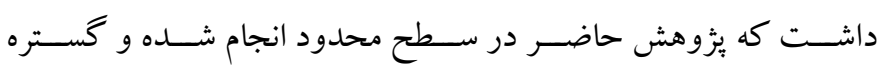

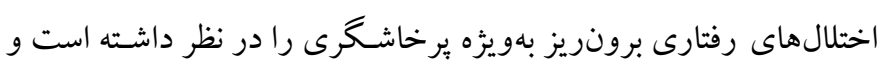

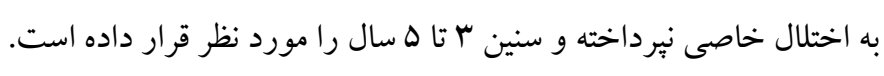

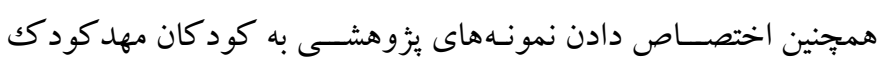

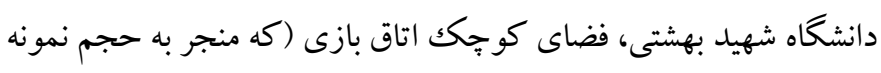

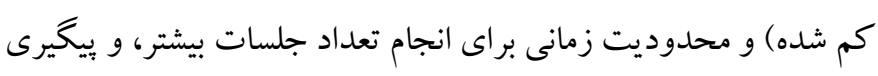

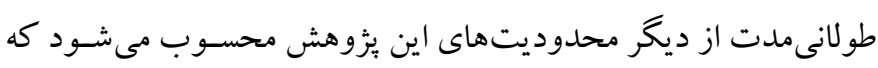

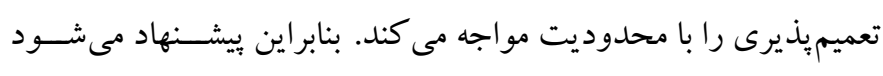

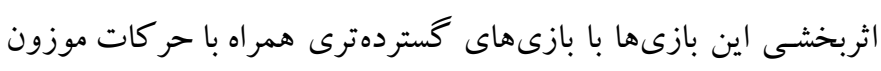

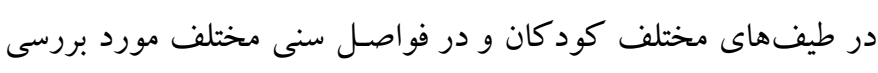

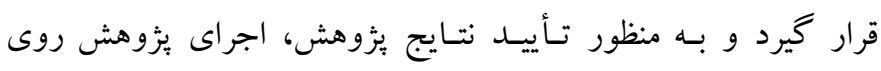




\section{References}

1. Pourshahriar H, Hashemi S, Aghaziarati A, Maleksheykhi S. Effectiveness of rhythmic movement games on improving attachment and reducing behavioral disorders in first and secondary elementary student's boys. Journal of Applied Psychology, 2018; 11, 4(44): 515-533. [Persian]. [Link]

2. Mostafavi S, Shaeeri M, Asghari Moghaddam M, Mahmoudi Gharaie J. Effectiveness of Educating Play Ther-apy Based on Child Parent Relationship Therapy (CPRT) According Landreth Model to Mothers on Reducing Child Behavioral Prob-lems. CPAP. 2013; 2 (7): 33-42. [Persian]. [Link]

3. Balali R, Aghayousefi A.R. The effectiveness of parental education program on reducing child behavioral problems. Journal of Applied Psychology, 2012; 5, 4(20): 59-73. [Persian]. [Link]

4. Carnes-Holt K. Child-Parent Relationship Therapy for Adoptive Families. The Family Journal. 2012; 20(4): 419-26. [Link]

5. Mirzaei F, Shakerinia I, Asghari F. The Associations between Parent-Child Relationship and Aggressive Behavior among Students. JCMH. 2016; 2 (4): 21-34. [Persian]. [Link]

6. Yaacob NRN, Siew HS. Mother working status and physical aggressive behavior among children in Malaysia. Procedia - Social and Behavioral Sciences. 2010; 5: 1061-1066. [Link]

7. Singh S, Lundy M, Haymes MV de, Caridad A. Mexican Immigrant Families: Relating Trauma and Family Cohesion. J Poverty. 2011, 15(4): 427-43. [Link]

8. Dewi KS, Prihatsanti U, Setyawan I, Siswati. Children's Aggressive Behavior Tendency in Central Java Coastal Region: The Role of Parent-Child Interaction, Father's Affection and Media Exposure. Procedia Environ Sci. 2015; 23: 192-8 [Link]

9. Rajab-Pour M, Makvand- Housseini Sh, Rafie- Nia P. The Effectiveness of Child-Parent Relationship Therapy on Aggression in Preschoolers. JCP, 2012; 4(1): 65-74. [Persian] [Link]

10. Akbari B, Rahmati F. The Efficacy of Cognitive Behavioral Play Therapy on the Reduction of Aggression in Preschool Children with AttentionDeficit/Hyperactivity Disorder.JCMH. 2015; 2 (2): 93-100. [Persian]. [Link]

11. Movallali G, Barati R, Taheri M. Efficacy of Social Skills Training on the Reduction of Verbal and Nonverbal Aggression in Male Students with
Intellectual Disability. JCMH. 2015; 1(1): 57-66. [Persian]. [Link]

12. Adams D, Allen D. Assessing the need for reactive behaviour management strategies in children with intellectual disability and severe challenging behavior. J Intellect Disabil Res, 2001; 45 (4): 335-343. [Link]

13. Riahi F, Amini F, Salehi Veisi M. The children's behavioral problems and their relationship with maternal mental health. 2012; 10 (1): 46-52. [Persian]. [Link]

14. Ferreira J.M. Makinen M. Amorim K.D.S. Intellectual disability in kindergarten: possibilities of development through pretend play. Procedia-Social and Behavioral Sciences. 2015: 217(1): 487-500. [Link]

15. Halperin J. M. Healey D. M. The influences of environment enrichment, cognitive enhancement, and physical exercise on brain development: can we alter the developmental trajectory of ADHD. Neuroscience and Bio Behavioral Reviews, 2011: 35(1): 621-634. [Link]

16. Bulotsky-Shearer R.J. Bell E. R. Romero S. L. Carter T. M. Preschool interactive peer play mediates problem behavior and learning for lowincome children. Journal of Applied Developmental Psychology, 2012, 33(1): 53-65. [Link]

17. Rafei T. Moving and playing games (rhythmic), coaches' guide, therapists and families. Tehran: Dangeh Publishing. Third edition. 2012, pp: 28-121. [Persian].

18. Gathercole S.E. The Assessment of Phonological Memory Skills in Preschool Children. J Educ Psychol, 1995; 65(2): 155-164. [Link]

19. Tajdini S, Pirkhaefi A. Effects oF Learning Games oN Improving Communication Skills and Social Rhythmic Autistic Children oF Urmia City. J Urmia Univ Med Sci. 2015; 26 (4): 268-280. [Persian]. [Link]

20. Freilich R, Shechtman Z. The contribution of art therapy to the social, emotional, and academic Adjustment of children with learning disabilities. The Arts in Psychotherapy, 2010; 37(9): 97-105. [Link]

21. Zolmajd A, Borjali A, Arian K. Impact of Sand Play Therapy on Reduction of Aggressive Behaviors. JOEC. 2007; 7 (2): 155-168 [Persian]. [Link]

22. Khodabakhshi koolaee A, Sabzian M, Falsafi nejad M $\mathrm{R}$. Impact of poetry therapy and movement/dance therapy in decreasing aggression and anxiety among preschool children. JPEN. 2015; 1 (4): 11-21. [Persian]. [Link] 
23. Nazari M. Movahedi A.R. \& Safavi Homami S. Effect of different combination of music and rhytmic movements on behavioral problems of 8-14-year-old boys with mental retardation. Motor Learning and Movement, 2015: 7(3): 311-331. [Persian]. [Link]

24. Bégel V, Di Loreto I, Seilles A, Dalla Bella S. Music Games: Potential Application and Considerations for Rhythmic Training. Front Hum Neurosci. 2017; 11(273): 1-7. [Link]

25. Barzegar Bafrooei K, Mirjalili M, shirahany A. The Role of Motion Games, Art and Music in Reducing Behavioral Problems in Children with Learning Disabilities. Exceptional Education. 2015; 7 (135): 52-62. [Persian] [Link]
26. Herbert W, Rand C.A, Franz G.J. Evaluating the effectiveness of Theraplay in treating shy, socially withdrawn children. International Journal of Play Therapy, 2011; 20(1): 26-37 [Link]

27. Sar A.H, Soyer F and Çolak T.S. The Effect of Educational Games on Dealing with Shyness of Elementary School Children (7-11 Years Old). Anthropologist, 2015; 19(3): 645-653 [Link]

28. Vahedi Sh, Fathiazar S, Hosseini-Nasab SD, Moghaddam M. Validity and reliability of the aggression scale for preschoolers and assessment of aggression in preschool children in Uromia. The Quarterly Journal of Fundamentals of Mental Health, 2008; 10(37): 15-24. [Persian]. [Link] 